University of Louisville

ThinkIR: The University of Louisville's Institutional Repository

Electronic Theses and Dissertations

1945

\title{
A study of factors influencing the hydrolysis of corn amylopectin by barley malt enzymes.
}

Thelma Munsey Back 1918-2006

University of Louisville

Follow this and additional works at: https://ir.library.louisville.edu/etd

Part of the Biochemistry Commons, and the Organic Chemistry Commons

\section{Recommended Citation}

Back, Thelma Munsey 1918-2006, "A study of factors influencing the hydrolysis of corn amylopectin by barley malt enzymes." (1945). Electronic Theses and Dissertations. Paper 1916.

https://doi.org/10.18297/etd/1916

This Master's Thesis is brought to you for free and open access by ThinkIR: The University of Louisville's Institutional Repository. It has been accepted for inclusion in Electronic Theses and Dissertations by an authorized administrator of ThinkIR: The University of Louisville's Institutional Repository. This title appears here courtesy of the author, who has retained all other copyrights. For more information, please contact thinkir@louisville.edu. 
UNIVERSITY OF LOUISVILLE

A STUDY OF FACTORS INFLUENCING THE HYDROLYSIS OF CORN AMYLOPECTIN BY

BARLEY MALT ENZYMES

\author{
A Dissertation \\ Submitted to the Faculty \\ of the Graduate School of the University of Louisville \\ In Partial Fulfillment of the \\ Recuirements for the Degree \\ of Master of Science
}

Department of Chemistry

by

Thelma Munsey Back

June, 1945 
NAME OF STUDENT: Thelme lunsey Back

TITLE OF THESIS: A Study of Factors Influencing the Hydrolysis of Com Amylopectin by Barley Malt Enzymes

APPEOVED BY READING COMAITTEE CORPOSED OF

THE FOLLOWING REABERS:

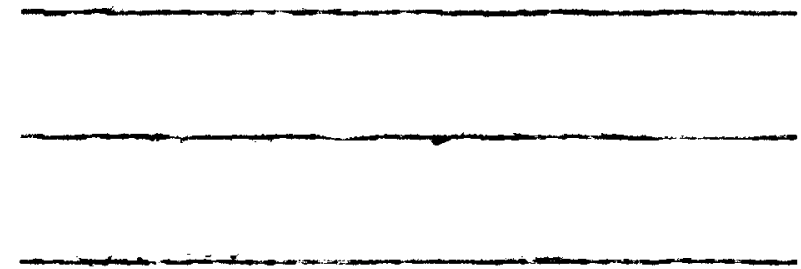

NAIE OF DIRECTOR:

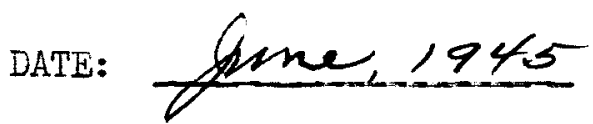




\section{ACKNOWLEDGMENTS}

The writer wishes to express her appreciation to Dr. C. C. Vernon, Acting Head of the Chemistry Department of the University of Louisville, for his counsel and guidance and for his kind cooperation in allowing the experimental work to be done in the Seagram Research Laboratories. Appreciation is also expressed to Dr. W. H. Stark, Director of Research of Joseph E. Seagram \& Sons, Inc., Louisville, Kentucky, for his generous contribution of helpful suggestions and criticisms concerning the problem and preparation of the manuscript. Sincere thanks are also due other members of the Seagram Organization, including Mr. M. C. Brockmann, for his suggestion of the original problem, Mr. Louis Manna, for his many suggestions, and Dr. Paul Kolachov, for his encouragement. 
CONTENTS

Introduction ....................... 1

Experimental . . . . . . . . . . . . . . 9

Studies on Hydrolysis and Fermentation of Whole Starch . . . 9

Hydrolysis and Fermentation Procedures . . . . . . . 9

Experimental Results and Discussion .......... 12

Hydrolysis Studies on Corn Starch Components . . . . . . 18

Preparation of the Starch Components . . . . . . . . 19

General Procedures. Used in Hydrolysis Studies . . . . . 24

Preparation of Materials .............. 24

Procedure for Malt Hydrolysis of Amylose and Amylopectin - 27

Calculation Methods .............. 36

Experimental Results and Discussion . . . . . . . 38

Hydrolysis of Amylose and Amylopectin Under Standard

Conditions ................. 38

Studies of Factors Affecting Malt Hydrolysis of

Amylopectin .................. 41

Effect of Temperature on Hydrolysis of Amylopectin

by Barley Malt... . . . . . . . . . . . . 41

Effect of $\mathrm{pH}$ on the Malt Hydrolysis of Amylopectin . . . 46

Effect of Ratio of Barley Malt to Amylopectin on the

Hydrolysis of the Amylopectin . . . . . . . 50

Effect of Various Malt Extraction Procedures on the

Power of the Malt to Hydrolyze Amylopectin . . . . . 55

Summary of Results and Conclusions ............ 64

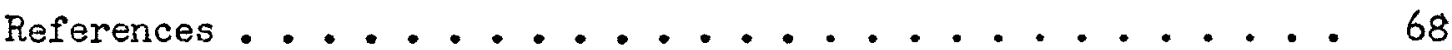


INTRODUCTION 


\section{INTRODUCTION}

Increased demand for ethyl alcohol and the necessity of producing this alcohol from cereal grains emphasizes the need for improvement in the manufacturing process. Probably the most inefficient phase of the manufacture is the method of converting the starchy portion of the grain to fermentable sugars. With present practices of conversion by malt, the procedure is costly and inefficient because of the large quantity of malt required, the relatively high cost of malt and the long fermentation period required for malt converted mashes. Apparently the primary reason for the inefficiency of malt conversion is the inability of the malt, under present industrial practices, to completely convert the starch to fermentable sugars. A substantial portion of the starch is converted to unfermentable dextrins, and the conversion of these dextrins (so called "secondary conversion") during fermentation is very slow. This results in need for a very large fermenter capacity, slower production of alcohol, and a greater chance for bacterial infection.

Obviously, the elimination or reduction of the time required for "secondary conversion" is highly important if not essential for the successful development of a completely continuous process of alcohol production. The cause of incomplete conversion is thought to be related to the structure of the components of starch. Although starch was for years thought to be a homogenous substance, it is now generally agreed that it is made up of two types of molecules, a linear chain type (amylose) and a branched chain type (amylopectin). 
Since starch is the ultimate source of alcohol produced from grain, a consideration of the structure of the components of starch is important to an understanding of the processes involved in the production of alcohol. According to Meyer (13) amylose is a homologous mixture of unbranched chains in which $100-700$ glucose residues are united in alpha 1:4 glucosidic arrangement while amylopectin is composed of large, very highly branched molecules containing 500-2,000 glucose residues. Other investigators claim that the amylopectin molecule consists of a central chain with long side branches. Freudenberg (9) and Myrback (19) have concluded that the branching in the amylopectin molecule is through a 1:6 alpha-glucosidic linkage.
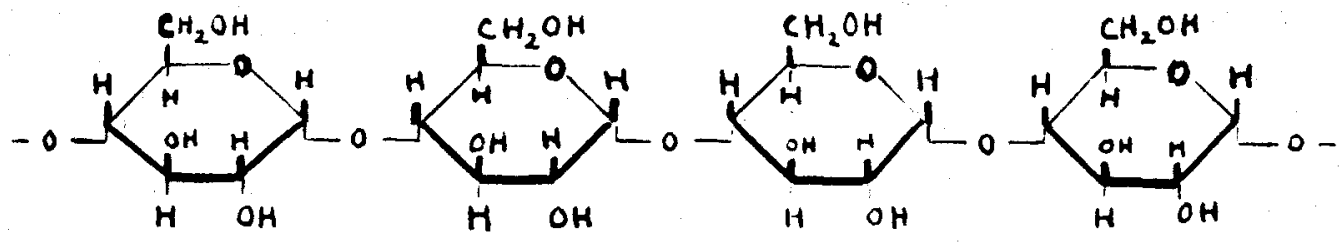

Section of Amrlose Chain



Section of Amylopectin Chain (Showing Brancih Poini) 
A survey of the literature shows that while amylose is practically completely converted to reducing sugar by malt amylases, the amylopectin fraction is incompletely converted. Kerr (8) concluded that almost 50 per cent of the anylopectin molecule is composed of linear branches, since this quantity of limit dextrin is formed from hydrolyzed amylopectin.

The starch degrading properties of barley malt are due primarily to the alpha- and beta-amylase content of the malt. Apparently the degrading action of a mixture of the amylases results first in liquefaction of gelatinized starch, then in rapid dextrinization followed and accompanied by saccharification until an apparent limit has been reached (9).

The action of pure beta-anylase upon starch results in the production of maltose and a high molecular weight dextrin, but no liquefaction or viscosity change occurs. The saccharification occuring during the first phase of the reaction is proportional to the enzyme concentration. During the latter stage, the reaction greatly decreases in rate and finally reaches a limit when 60 per cent of the starch has been converted. From this action it is assumed that the beta-amylase removes maltose from the non-aldehydic end of starch chains $(20,19)$.

The amylose component of starch is completely hydrolyzed by beta-amylase $(28,18)$. A very small amount of glucose is apparently formed at the same time $(6,7)$. For the greater part of the hydrolysis of amylose by beta-amylase, the reaction is of zero order, indicating 
continuous splitting off of maltose units from end groups and the continuous formation of new end groups $(16,17)$. After the complete hydrolysis of some chains, the concentration of the substrate is reduced with a resultant decrease in hydrolysis rate.

If pure alpha-amylase is used as a conversion agent, there is no linear relationship between concentration of the enzyme and reducing value. This is apparently due to the reaction being first one of dextrinization followed by splitting of the dextrin to form sugars rather than a direct action on starch. With sufficient time, the saccharification may proceed to the same extent as would be possible using a mixture of alpha- and beta-amylase (10).

The various studies on highly purified amylase components, while very necessary and helpful, cannot give a true representation of the action of an enzymatic mixture such as occurs in barley malt. It is well known, for instance, that a mixture of alpha- and betaamylase results in greater hydrolysis of starch than if either of the amylases acts alone (21, 22, 38, 35). Freeman and Hopkins (3) claim that the alpha- and beta-amylase activity is additive at low, but not high, enzyme concentrations, and not additive when the beta-amylase is high relative to the alpha-amylase.

Since the additive relationship holds for saccharogenic activity by alpha- and beta-amylases, it is apparent that alphaamylase contributes to malt saccharification, but the magnitude of its influence is uncertain. Data obtained by Hills and Bailey (5), 
however, indicate that 25 to 29 per cent of the saccharification action of barley malt is due to the alpha-amylase component. It is claimed also that the saccharogenic activity of alpha-amylase is proportional to its dextrinogenic activity $(20,19)$.

There is good correlation between beta-amylase activity of a malt and its saccharogenic power, but while saccharification is the main function of the beta-amylase, another function is indicated by the fact that the presence of beta-amylase increases the rate of dextrinization by alpha-amylase (29).

To summarize, both dextrinization and saccharification are the result of the combined action of alpha- and beta-amylase and both processes proceed more rapidly and to a greater degree in the presence of an enzymatic mixture than with either amylase alone.

According to Meyer (14) the hydrolysis of amylopectin by beta-amylase yields a high molecular weight substance which amounts in the case of corn amylopectin to 45 per cent of the original amylopectin. The rate of hydrolysis of this material (residual dextrin I) is $\frac{1}{300,000}$ that of the original rate of hydrolysis. Apparently the incompleteness of the hydrolysis is due to the betaamylase encountering some configuration in the chain that acts as an obstacle to further action $(6,7)$. The remaining residual dextrin I although practically immune to beta-amylase may be attacked through an alpha bond by alpha-amylase, (or by alpha-glucosidase, or super heated water) to yield residual dextrin II, which is then subjected to 
further hydrolysis by beta-amylase to yield maltose and residual dextrin III. The scheme for the enzymatic degradation of amylopectin is pictured by Meyer in the following diagram (15):

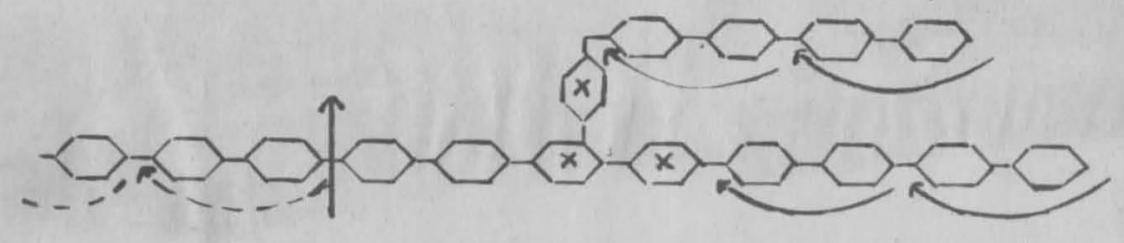

$\boldsymbol{X}$ atteck by beta-amy lise

branch point (orevent continued hydroly eis - recidual dextrin I renains)

$\uparrow$ cleavape by alpha-amylese of superr...' subsequent sttack by betr-emylase

Fermentation studies on starch and starch fractions also yield information indicative of the mechanism of malt action on starch. Unfortunately, however, the action of malt amylase in the presence of yeasts is not well understood.

During fermentation, unfermentable dextrins formed by the action of malt amylases during the conversion period are apparently slowly converted to fermentable sugars. There are a number of possible explanations for this:

(1) If the theory is correct that some configuration in the amylopectin is the cause of stoppage of hydrolysis after approximately 60-70 per cent has been hydrolyzed, it is possible that some substance 
(possibly alpha-glucosidase) produced by yeast during the fermentation process acts on this configuration and thus opens up more of the molecule to the action of the remaining amylase.

(2) It has also been suggested that incomplete hydrolysis by enzymes is due to the attainment of an equilibrium in the reaction and that further hydrolysis is impossible until the product of the reaction, maltose, is removed. This removal of maltose occurs during the fermentation process and thus more maltose may be formed.

Pigman (24) suggests that an equilibrium may be attained when approximately 10 per cent unfermentable substance remains in the reaction mixture. In support of this theory, he presented data showing that when malt amylases were destroyed previous to fermentation, 89 per cent of the theoretical yield of alcohol was obtained for corn starch and 90 per cent for waxy maize starch (amylopectin). (In his experiment, contersion was carried on over a period of 5 days at $57^{\circ} \mathrm{C}$. previous to destruction of the enzyme and addition of veast. The calculations were based on 39.5 per cent maximum fermentation efficiency.) When the unfermentable material, after renoval of fermentable sugars, was resubjected to amylase action, the unfermentable material was reduced from 10 per cent to 4 per cent.

When the fermentation was carried out in the presence of malt amylases, the efficiency of the process was increased; corn starch gave 101.9 per cent and waxy maize sterch (amylopectin) gave 100 per cent jield of alcohol (25). 
8.

The study reported herein was undertaken to determine experimentilly the degree of malt hydrolysis end fermentation behavior (in the presence and absence of amylase) of starches containing different proportions of starch components, and then by further studies, to determine the effects of various factors on the hydrolysis of that fraction of starch that resists hydrolysis. The object was to find optimum conditions for the hydrolytic action of barley malt on starch in order to increase the degree of conversion previous to fermentation, and to reduce, if possible, the quantity of melt regored for conversion. 
EXPERTMENTAL 


\section{EXPERDVENTAL}

Studies on Hydrolysis and Fermentation of hole Starches

Preliminary experimental work on malt hydrolysis of sterches for various periods of time followed by fermentation was necessary to cemonstrate the effect of the amylases durine fementation and to show the effect of hydrolysis time and the difference in fermentability of the starch components. It was also considered desirable to compare the degree and rate of malt hydrolysis of starch as shown by reducing sugar determinations vith the quantity of fermentable sugar produced under like condjtions of hydrolysis. It has been common practice to determine the degree of hydrolysis by reducing sugar determination. Actually, however, in alcohol production, it is the fermentable sugar which is the important factor; the reducirg suger value is only an indirect measure of the fermentable sugar and is quite probably influenced by the presence of reducing meterials, formed during the hydrolysis of starch, which are not fermenteble.

\section{Hydrolysis and fermentation Procedures}

Procedure A: standard procedure described by Stark, Adams, Scalf, and Kolachov (36).

Accurately weighed $160 \mathrm{gm}$. samples of waxy maize starch and corn starch were pre-malted, pressure cooked, and hydrolyzed for one hour with barley malt ( 13 per cent based on weight of starch) according to the standard method. Dried solubles ( 10 per cent, based on weight of the starch) were added as a yeast nutrient. Blanks containing 
all constituents except starch were also min so that necessary corrections to final data could be made. Conversion temperature and $\mathrm{pH}$ were $63^{\circ} \mathrm{C}$. and 5.3 respectively. The $\mathrm{pH}$ was adjusted to 4.8 before th yeast (saccharonyces cerevisiae) was added. Fermentation proceeded for 66 hours at $28^{\circ} \mathrm{C}$. Acidity and $\mathrm{pH}$ after fermentation were determined in order to confirm freedom from bacterial contamination.

Procedure B: Kodification of Procedure A (Used in studies on hydrolysis by malt followed by fermentation in the presence and absence of the amylases)

A suspension of corn starch and another of waxy maize starch in filtered yeast water ( 10 per cent yeast in water, autoclaved and filtered) buffered at $\mathrm{pH} 5.5$ with phosphate buffer, were held at $63^{\circ} \mathrm{C}$. with constant stirring for 10 minutes. The mixtures were then autoclaved for 1 hour at 22 lbs. per so. inch pressure; after cooling to $70^{\circ} \mathrm{C}$, each of the starch dispersions was made to 1 liter. Aliquots $(175 \mathrm{ml}$.$) were removed and put in sterile, tared fermenters which had$ been placed previously in a water bath adjusted to $63^{\circ} \mathrm{C}$. (The fermenters used were $250 \mathrm{ml}$. centrifuge tubes.) Malt extract was added to each fermenter from a sterile pipette; each fermenter was then held at the hydrolysis temperature for periods of time ranging from 15 to 120 minutes. At the end of the specified conversion time, enzyme activity was destroyed by placing the fermenter in a boiling water bath for 15 minutes. The fermenters were cooled and the pH adjusted to 4.8. After weighing the fermenter and total contents, a $5 \mathrm{ml}$. portion 
was removed for sugar analysis and accurately weighed. Reducing and total sugers were determined on the weighed samples. A control sample in which enzyme action was not destroyed by boiling, and a number of blanks containing all constituents except starch were also run so that corrections to the final data could be made. The fermentation of all the samples was allowed to proceed for 66 hours at $28^{\circ} \mathrm{C}$.

In both Procedure $A$ and $B$, sugar analyses were made by the method of Stiles, Peterson and Fred (39). The table used for calculating the sugar quantity from the titration difference found is given on page 35. Alcohol determinations were made on distilled samples by determining the refractive index of the distillate with a Zeiss immersion refractometer and the results calculated from velues given in "Neudruck der Tabellen fur Aethyl-A]kohol" by Wagner (40).

\section{CALCULATION METHODS}

Degree of hydrolysis, expressed as per cent conversion, was calculated as the reducing sugar expressed as maltose divided by the total sugar (glucose) derived from acid hydrolysis of the initial starch times 105.2.

Efficiency data were calculated on the basis of one molecule of glucose producing two molecules of alcohol. Plant efficiency was calculated as actual alcohol produced divided by the theoretical alcohol based on the total sugar, times 100. Fermentation efficiency was calculated as actual alcohol divided by theoretical alcohol based on total sugar fermented, times 100 . 
Experimentel Results and Discussion

TABLE I

Hydrolysis and Fermentation Behavior of Corn Starch and Waxy Maize Starch under Standard Conditions of Distillery Practice.*

\begin{tabular}{|c|c|c|c|c|c|c|c|}
\hline \multirow[b]{2}{*}{ Starch Variety } & \multirow{2}{*}{$\begin{array}{l}\text { Total Sugar } \\
\text { (calculated } \\
\text { as glucose) } \\
\text { per cent }\end{array}$} & \multirow{2}{*}{$\begin{array}{l}\text { Reducing } \\
\text { Sugar } \\
\text { (calculated } \\
\text { as maltose) } \\
\text { per cent }\end{array}$} & \multirow[b]{2}{*}{$\begin{array}{c}\text { Conversion } \\
\text { per cent }\end{array}$} & \multirow{2}{*}{$\begin{array}{l}\text { Final Sugar } \\
\text { (Calculated } \\
\text { as glucose) } \\
\text { per cent }\end{array}$} & \multirow[b]{2}{*}{$\begin{array}{c}\text { Sugar } \\
\text { Fermented } \\
\text { per cent }\end{array}$} & \multicolumn{2}{|c|}{ Efficiency } \\
\hline & & & & & & $\begin{array}{c}\text { Formentation } \\
\text { per cent }\end{array}$ & $\begin{array}{l}\text { Plant } \\
\text { per cent }\end{array}$ \\
\hline Corm Starch:* & 9.64 & 7.52 & 82.1 & $\begin{array}{l}0.84 \\
0.82 \\
0.89\end{array}$ & $\begin{array}{l}91.3 \\
91.5 \\
91.6\end{array}$ & $\begin{array}{l}96.7 \\
96.9 \\
97.6\end{array}$ & $\begin{array}{l}88.2 \\
89.1 . \\
89.4\end{array}$ \\
\hline $\begin{array}{l}\text { Waxy Maize:sto: } \\
\text { Starch }\end{array}$ & 10.52 & 7.89 & 78.7 & $\begin{array}{l}0.97 \\
1.08 \\
0.94\end{array}$ & $\begin{array}{l}90.8 \\
89.7 \\
91.1\end{array}$ & $\begin{array}{l}93.8 \\
94.6 \\
94.5\end{array}$ & $\begin{array}{l}85.1 \\
84.9 \\
86.0\end{array}$ \\
\hline
\end{tabular}

*Procedure A was used - (one hour hydrolysis at $63^{\circ} \mathrm{C}$.) *** (79 per cent amylopecting, 21 per cent amylose (30)) * Amylopectin 
As would be expected from the greater amylopectin content of waxy maize starch, the conversion of waxy maize starch was less than that for corn starch. The waxy maize starch also showed a slightly lower production of fermentable sugar and a significantly lower fermentation and plant efficiency than com starch. Final residual totel sugar (calculated as glucose) was higher for waxy maize starch. These results indicate strongly that the amylopectin fraction of starch presents obstacles to conversion to fermentable sugars; it appears, too, that the reducing substance formed is less fermentable than that from the amylose fraction.

As expected, the data show that more sugar was fermented than was produced by maIt hydrolysis previous to fermentation. This indicates that further conversion occurs during fermentation.

In order to determine the effect of the malt amylases on this secondary conversion, fermentations were conducted in the presence and absence of the amylases. Also included in this study were experiments to show the effect of hydrolysis time. "Procedure B", described under hydrolysis and fermentation procedures was used. The results are summarized in Table II which follows. 
Hydrolysis of Corm Starch and Waxy Maize Starch in Relation to Time of Hydrolysis and Fermentation of these Starches in the presence and Absence of the Malt Amylases

\begin{tabular}{|c|c|c|c|c|c|c|c|c|c|}
\hline \multirow{3}{*}{ Starch } & \multirow{3}{*}{$\begin{array}{l}\text { Pre- } \\
\text { Fermen- } \\
\text { tation } \\
\text { Treat- } \\
\text { ment }\end{array}$} & \multirow{3}{*}{$\begin{array}{l}\text { Hydrol- } \\
\text { ysis } \\
\text { Time } \\
\text { Minutes }\end{array}$} & \multirow{2}{*}{$\begin{array}{l}\text { Total } \\
\text { Sugar } \\
\text { calcu- } \\
\text { lated } \\
\text { as } \\
\text { glucose }\end{array}$} & \multirow{2}{*}{$\begin{array}{l}\text { Reducing } \\
\text { Sugar } \\
\text { calcu- } \\
\text { lated } \\
\text { as } \\
\text { maltose }\end{array}$} & \multirow{2}{*}{$\begin{array}{c}\text { Conver- } \\
\text { sion } \\
\text { (Previous } \\
\text { to } \\
\text { Fermenta- } \\
\text { tion) }\end{array}$} & \multirow{2}{*}{$\begin{array}{l}\text { Final } \\
\text { Sugar (UN- } \\
\text { fermented } \\
\text { sugar } \\
\text { calcu- } \\
\text { lated as } \\
\text { glucose) }\end{array}$} & \multirow[b]{2}{*}{$\begin{array}{l}\text { Suger } \\
\text { Fermen- } \\
\text { ted. }\end{array}$} & \multicolumn{2}{|c|}{ Efficiency } \\
\hline & & & & & & & & $\begin{array}{c}\text { Fermenta- } \\
\text { tjon }\end{array}$ & Plant \\
\hline & & & per cent & per cent & per cent & per cent & per cent & per cent & per cent \\
\hline
\end{tabular}

\begin{tabular}{|c|c|c|c|c|c|c|c|c|c|}
\hline $\begin{array}{l}\text { Com } \\
\text { Starch } \\
\text { Composi- } \\
\text { tion: } 79 \\
\text { per cent }\end{array}$ & $\begin{array}{l}\text { amylases } \\
\text { destroyed } \\
\text { by heat }\end{array}$ & $\begin{array}{l}60 \\
15\end{array}$ & $\begin{array}{l}7.96 \\
7.71\end{array}$ & $\begin{array}{l}5.80 \\
5.51\end{array}$ & $\begin{array}{l}76.7 \\
75.2\end{array}$ & $\begin{array}{l}2.46 \\
2.51\end{array}$ & $\begin{array}{l}69.1 \\
67.5\end{array}$ & $\begin{array}{l}92.9 \\
94 . \dot{L}\end{array}$ & $\begin{array}{l}64.1 \\
65.7\end{array}$ \\
\hline $\begin{array}{l}\text { amylopec- } \\
\text { tin, } 21 \text { pe } \\
\text { cent amy- } \\
\text { lose }(30)\end{array}$ & $\begin{array}{l}\text { er } \\
\text { amylases } \\
\text { not des- } \\
\text { troyed. }\end{array}$ & 30 & 7.91 & 5.79 & 76.9 & .25 & 96.8 & 100.6 & 97.5 \\
\hline \multirow{2}{*}{$\begin{array}{l}\text { Waxy } \\
\text { Maize } \\
\text { Starch } \\
\text { (Amylo- } \\
\text { pectin) }\end{array}$} & $\begin{array}{l}\text { amylases } \\
\text { destroyed } \\
\text { by heat }\end{array}$ & $\begin{array}{r}120 \\
60 \\
15\end{array}$ & $\begin{array}{l}9.47 \\
9.38 \\
9.30\end{array}$ & $\begin{array}{l}6.83 \\
6.73 \\
6.36\end{array}$ & $\begin{array}{l}76.5 \\
75.0 \\
72.0\end{array}$ & $\begin{array}{l}2.89 \\
3.17 \\
3.43\end{array}$ & $\begin{array}{l}69.3 \\
66.2 \\
63.1\end{array}$ & $\begin{array}{l}93.4 \\
92.8 \\
98.0\end{array}$ & $\begin{array}{l}64.7 \\
61.5 \\
61.9\end{array}$ \\
\hline & $\begin{array}{l}\text { amylases } \\
\text { not des- } \\
\text { troyed }\end{array}$ & 30 & 9.43 & 6.92 & 77.2 & 0.99 & 89.5 & $94 \cdot 7$ & $84 . ?$ \\
\hline
\end{tabular}


Analysis of the data in Table II reveals the following:

Hydrolysis for 30 minutes at $63^{\circ} \mathrm{C}$. prior to fermentation, and fermentation in the presence of the malt amyloses, resulted in higher than normal efficiencies for corn starch (compare with data in Table I.) The results for waxy maize starch treated in a similar manner show a relatively lower per cent sugar fermented, lower plant efficiency, lower fermentation efficiency and higher residual, unfermentable material. The results check well with those presented in Table I. Apparently the greater amylopectin content of the waxy maize starch is responsible for the lower alcohol yield due to the difficulty of attaining complete conversion.

With both corn starch and waxy maize starch the fermentable sugar was greater than the initial quantity of reducing sugar produced by hydrolysis. This observation is important because it indicates that some co-action of malt and yeast results in further hydrolysis of dextrin (from the original starch) to fermentable sugar during the fermentation process. Neither malt alone nor yeast alone can cause this. Pigman (26) found in his studies that the amount of fermentable material formed by beta-emylase appeared to be the same whether fermentation was conducted in the presence or absence of amylases. Using whole malt or alpha-amylase, fermentation in the presence of anylases resulted in a greater conversion to fermentable substance. If this is correct, it is strong support of the concept of the importance of alpha-amylase during fermentation and indicates that alpha-amylase in conjunction with yeast may be 
responsible for additional hydrolysis of dextrin during fermentation. The data obtained by Pigman (26) indicated higher conversion than that show by the data presented here; this is probably due to the much more prolonged hydrolysis treatment used by Pigman.

If malt amylases were destroyed by heat prior to fermentation, the per cent sugar fermented was less than the per cent reducing sugar (indicated by the conversion value). This indicates that the reducing value as such is not an accurate measure of the fermentable sugars, but is apparently only roughly proportional to the fermentable sugars. It also indicates that yeast or substances produced by yeast are incapable of further hydrolyzing dextrins, when malt amylases are not present.

Hydrolysis for different periods of time at $63^{\circ} \mathrm{C}$. , followed by fermentation in the absence of amylases, indicates formation of only slightly more fermentable sugar (less than 3 per cent) for a one-hour hydrolysis period than for a 15 minute hydrolysis period. The per cent fermentation efficiency is significantly higher for short time conversion; it appears then that the reducing substances first formed in the hydrolysis process are more fermentable than the reducing substances formed later.

The plant efficiency data tend to rise slightly with hydrolysis time for corn starch and to fall slightly for waxy maize. Most significant is the fact that plant efficiency is approximately as high at 15 minutes as at one hour for both starches. 
There seems to be no advantage in a hydrolysis time in excess of 15 minutes.

It is well known that prolonged exposure of amylases to heat is detrimental to their action and may even cause inactivation. Therefore, the fact that short hydrolysis period is sufficient is important because such a treatment may be expected to leave the amylase in a much more active condition to act on dextrin during the fermentation process. 


\section{Hydrolysis Studies on Corn Starch Components}

Results obtained in the hydrolysis and fermentation studies on corm starch and waxy maize starch show that using standard distillery procedures, the production of fermentable sugars previous to fermentation is significantly lower for a starch of higher amylopectin content, and this is further reflected in the alcohol yields. To show more clearly the difference in the degree of hydrolysis of the two components of starch, amylose and amylopectin, further studies on the pure components were necessary. In order to prepare pure components from starch, it was first necessary to devise a procedure for preparing pure starch with the structure as unaltered as possible and then to fractionate the starch into its components. Finally it was necessary to develop a procedure for studying the rate and degree of hydrolysis of the starch components. 


\section{Preparation of the Starch Components}

The Preparation of Pure Starch:

The preparation of pure starch presents a definite problem since the method of preparation necessarily involves both steeping in water and grinding; both of these processes must be rigidly controlled in order to avoid chemical action on the starch and changes in the starch structure.

The separation of pure corn starch is essentially a separation of the starch in the corn grain from the other components of the grain. The corm grain is composed of a hull surrounding the germ and the endosperm. Non-starchy carbohydrates plus some inorganic material compose the hull while the germ contains low melting natural fats, soluble proteins, and inorganic salts. The endosperm is made up of a soft crown containing large granules of easily released starch and a horny portion containing starch embedded in water-insoluble protein; the embedded starch is much more difficult to separate than the crown starch.

In the commercial manufacture of starch, extended steeping periods in acidified.water at relatively high temperatures along with further chemical treatment are necessary to achieve a good yield of starch. The crown starch can certainly be expected to be affected by this treatment (11).

In the experimental work reported in this paper, pure, 
unaltered corn starch was desired. The laboratory procedure developed is similar to the commercial process, but numerous modifications were necessary. Modifications included the use of the "single steep" system, shorter steeping time at lower temperature, very coarse grinding (to break up the softened grain), and the use of only physical means thereafter in the separation of the starch. Methanol ( 85 per cent) was used to remove fatty impurities. Relatively low temperature drying was employed after the methanol extraction.

Experimental Procedure for Preparation of Pure Starch:

Two kilograms of the cleaned com grain were washed thoroughly and then steeped for 24 hours in approximately twice its volume of distilled water containing 0.2 per cent $\mathrm{SO}_{2}$ and at a temperature of 460 - 500 C. Rigid control must be maintained during steeping since any maladjustment may result in hydrolysis of the starch. After thorough washing with distilled water, the softened grain was then coarsely ground and distilled water added. The mixture was allowed to stand for one to two hours (with frequent agitation); the pulpy mass was then poured into nylon mesh bags, drained, and pressed. The mass in the bag was further extracted with distilled water until only a negligible amount of starch appeared in the wash water. The starch - gluten suspension so obtained was filtered through a double layer of nylon mesh and the solids of the filtrate allowed to settle. After removal of the supernatant Iiquid by siphoning, the remaining thick suspension was centrifuged at 2,000 r. p. m. for five minutes. The top or gluten layer was removed 
by scraping. The starch was resuspended in distilled water, recentrifuged and the gluten layer again removed by scraping. The process was repeated until the gluten layer was completely removed.

To remove oil and other impurities, the method of Schoch (31) was used. White starch was suspended in 85 per cent (by volume) methanol and heated, with continuous agitation, in a water bath at $60^{\circ}-70^{\circ} \mathrm{C}$. for two hours. After filtering the hot methanolstarch mixture through a Buchner funnel, the starch was washed with two portions of fresh methanol. The extraction process was repeated four times. The starch was then spread on a large sheet of filter paper and dried at low temperature by means of heat from an infra-red heating Iight.

Fractionation of Defatted Corn Starch:

The separation of the components of starch was accomplished by a method of selective precipitation with butanol as described by Schoch $(32,33)$ (with modifications). It has been show that the fraction of starch precipitated by butanol is made up of linear chains (amylose) and the non-precipitated fraction contains branched chains (amylopectin) (27).

Details of the fractionation method used are as follows: $80 \mathrm{gm}$. of defatted corm starch in $400 \mathrm{ml}$. of distilled water was added slowly and with constant stirring to a boiling mixture composed of 4 liters of water and $400 \mathrm{ml}$. of butanol. The mixture was then autoclaved for 2 hours at 18-20 1bs./in. ${ }^{2}$ pressure. After autoclaving, 
the 0.4-1.0 per cent undispersed material was removed by passing the hot liquid through a Sharples super centrifuge fitted with a clarifier bowl and operating at $25,000 \mathrm{r} . \mathrm{p}$. m. An additional $200 \mathrm{ml}$. of butanol and 100-200 ml. of iso-amyl alcohol were added to the hot liquid. The flask was then insulated with a thick layer of cloth and allowed to cool slowly to room temperature over a period of 48 hours in order for the amylose to come out of "solution".

To remove the amylose, the liquid containing the starch fractions was passed through the super centrifuge at a rate of approximately 5 liters per hour; the amylose was deposited in the rotor of the centrifuge as a thick white cream. Completeness of the separation was determined by observing a drop of the centrifugate under a microscope. Presence of amylose in the liquid was indicated by the appearance of segmented spherulites. A second centrifuging, if necessary, removed remaining amylose. The amylose was removed from the bowl of the centrifuge as rapidly as possible (to avoid retrogradation) to a storage container half filled with butanol, and the precipitate was broken up under the butanol. The amylase was stored in this way to prevent drying and moisture effects. Amylose purification, consisting of thorough washing with butanolsaturated water, was carried out just before use of the amylose.

After removal of the amylose, the remaining liquid was filtered through absorbent cotton and allowed to stand over night in the presence of fresh cotton. After refiltering through cotton, methanol was added until the amylopectin was dehydrated and settled 
out. The liquid surrounding the amylopectin was decanted and the amylopectin fraction purified by redispersion in bofling water, filtration through cotton and subsequent over night standing in contact with cotton. Finally the amylopectin was reprecipitated with methanol, separated from the remaining liquid and then stored under methanol.

The method described here is essentially the method of Schoch (30). The modifications were in the addition of butanol and iso-amyl alcohol to the hot dispersion after the removal of undispersed material and a longer standing time before removal of the anylose. This procedure seemed to be more efficient in the separation of this fraction. Filtration of the liquid (after removal of amplose) through cotton, and standing in contact with cotton, was an obvious and simple purification step. It was shown by Pacsu and Mullen (23) that cotton selectively absorbs amylose. 
General Procedures Used in Hydrolysis Studies

Preparation of Materials:

Concentrated stock amylopectin dispersion: Purified amylopectin was added to boiling water ( $13 \mathrm{gm}$. to $100 \mathrm{ml}$.$) and stirred$ constantly for 2-3 minutes. The temperature was then lowered to $69^{\circ}-70^{\circ}$ C., and a quantity of malt extract (equivalent in amount to 0.5 per cent malt based on amylopectin) was added to effect liquefaction; this malt extract had previously been held at $680 \mathrm{c}$. - 700 c. for 2-3 minutes. After further vigorous stirring, toluene was added as a preservative.

Dilute stock amylopectin dispersion: Amylopectin was added to boiling water ( $2 \mathrm{gm}$. to $100 \mathrm{ml}$.$) and stirred constantly$ for 2-3 minutes. Toluene was added as a preservative.

Amylose dispersion: Just before use, amylose was purified by repeated washing with butanol-saturated water, then methanol and finally water. Approximately $17 \mathrm{gm}$. of the wet amylose were then immediately added with stirring to $300 \mathrm{ml}$. boiling water. The hot mixture was filtered into a $500 \mathrm{ml}$. volumetric flask previously placed in a water bath at $630 \mathrm{C}$. The $\mathrm{pH}$ of the mixture was adjusted to 5.5 with phosphate buffer and the whole made to volume with distilled water at $63^{\circ} \mathrm{C}$.

Buffer solutions: Several buffer solutions were prepared. The composition and relative volumes of each constituent of the 
various buffers prepared is indicated in the following table.

Preparation of Buffers

\begin{tabular}{|c|c|c|c|c|c|c|}
\hline \multirow[b]{3}{*}{ Buffer } & \multirow[b]{3}{*}{$\mathrm{pH}$} & \multicolumn{2}{|c|}{ Buffer Composition } & \multicolumn{3}{|c|}{$\begin{array}{l}\text { and Volume of Each Constituent } \\
\text { (ml.) }\end{array}$} \\
\hline & & $\frac{0.2 \mathrm{M}}{\mathrm{KH}_{2} \mathrm{PO}_{4}}$ & $\frac{0.2 \mathrm{M}}{\mathrm{Na}_{2} \mathrm{HPO}_{4} \cdot 12 \mathrm{H}_{2} \mathrm{O}}$ & $\begin{array}{c}\mathrm{O} .1 \mathrm{M} \\
\mathrm{C}_{6} \mathrm{H}_{8} \mathrm{O}^{\circ} \mathrm{H}_{2} \mathrm{O} \mathrm{KH} \\
(\mathrm{Citric} \text { Acid) }\end{array}$ & $\begin{array}{l}0.2 \mathrm{M} \\
\text { Phtalate }\end{array}$ & $\begin{array}{l}0.2 \mathrm{M} \\
\mathrm{NaOH}\end{array}$ \\
\hline & & ml. & $\mathrm{ml}$. & $\mathrm{ml}$ & $\mathrm{ml}$. & $\mathrm{ml}$. \\
\hline $\begin{array}{l}\text { "Phosphate I" } \\
(34)\end{array}$ & $\begin{array}{l}4.8 \\
5.0 \\
5.3 \\
5.5 \\
6.0 \\
6.3 \\
6.4 \\
6.7\end{array}$ & $\begin{array}{l}99.5 \\
99.0 \\
98.0 \\
96.0 \\
88.0 \\
77.2 \\
73.5 \\
57.0\end{array}$ & $\begin{array}{r}0.5 \\
1.0 \\
2.0 \\
4.0 \\
12.0 \\
22.8 \\
26.5 \\
43.0\end{array}$ & & & \\
\hline "Phosphate IT" & $\begin{array}{l}4.6 \\
4.8 \\
4.9 \\
5.0 \\
5.1 \\
5.3 \\
5.5 \\
6.3\end{array}$ & & $\begin{array}{r}9.4 \\
9.9 \\
10.1 \\
10.3 \\
10.5 \\
10.9 \\
11.4 \\
13.6\end{array}$ & $\begin{array}{l}15.6 \\
15.1 . \\
14.9 \\
14.7 \\
14.5 \\
14.1 \\
13.6 \\
11.4\end{array}$ & & \\
\hline $\begin{array}{l}\text { "Phthalate" } \\
\text { (2) }\end{array}$ & $\begin{array}{l}5.0 \\
5.3 \\
5.5 \\
5.7 \\
6.0\end{array}$ & & & . & $\begin{array}{l}50 \\
50 \\
50 \\
50 \\
50\end{array}$ & $\begin{array}{l}23.9 \\
32.3 \\
36.7 \\
40.5 \\
45.5\end{array}$ \\
\hline
\end{tabular}


Standard Malt Bxtract:

The standard (unbuffered) malt extract was made by adding distilled water to $16.8 \mathrm{gm}$. of freshly ground barley malt to make a volume of $100 \mathrm{ml}$. The mixture was shaken frequently during the 2.5 hour extraction period and was then centrifuged for 10-15 minutes at 3,000 r. p. m. The extract was then decanted from the solid portion and preserved with toluene. Fresh malt extract was prepared each day unless otherwise indicated. In all the studies reported here the same malt was used throughout; this was a distillers' barley malt. The malt extract was more concentrated than that normally used in conversion studies because it has been show that both amylases of malt are more stable in a concentrated than a dilute extract (12). This malt extract was used in all experimental studies unless otherwise indicated.

Special Malt Extracts:

A. Malt Extracted at Various $\mathrm{pH}$ Levels and at Various Temperatures: Unit quantities ( $8.4 \mathrm{gm}$ ) of freshly ground barley malt were added to $25 \mathrm{ml}$. portions of $0.2 \mathrm{M}$ "phosphate buffer I" at six different $\mathrm{pH}$ levels $(4.7,5.2,5.5,6.2,6.4$, and 6.7). Water was added to each portion to make a total volume of $50 \mathrm{ml}$. Then after thorough agitation, each $50 \mathrm{ml}$. portion was divided into two $25 \mathrm{ml}$. portions. Thus, six pairs of $25 \mathrm{ml}$. samples were obtained. One of each pair was kept for 2.5 hours at room temperature, while the other was kept in a constant temperature water bath at $55^{\circ} \mathrm{C}$. In this way, $\mathrm{pH}$ and tempera- 
ture were varied. At the end of extraction, the malt mixtures were centrifuged and the extracts preserved with toluene.

B. Malt extracted under various temperature conditions:

Three $16.8 \mathrm{gm}$. portions of freshly ground barley malt were each made to $100 \mathrm{ml}$. with distilled water. The first (control) was extracted for 2.5 hours at room temperature. The second portion was subjected to a short heat treatment -- extraction for 15 minutes at $37^{\circ} \mathrm{C}$., followed by 15 minute extraction at $55^{\circ} \mathrm{C}$. The third portion received prolonged heat treatment -- extraction for 2.5 hours at $55^{\circ} \mathrm{C}$.

After extraction each malt sample was centrifuged. The malt extract was then preserved with toluene.

Procedure for Malt Hydrolysis of Amylose and Amylopectin

In order to devise a standard hydrolysis procedure, it was necessary to first make preliminary studies on the effect of the quantity of phosphate buffer used, the effect of the quantity of malt extract used for hydrolysis at various temperatures, and the effect of the concentration of amylose and amylopectin.

It was found that with the use of over a certain minimum quantity of phosphate buffer, the quantity of buffer had no significant effect on the hydrolysis.

To determine the effect of the quantity of malt on the degree of hydrolysis, samples of a 1 per cent amylopectin dispersion buffered at $\mathrm{pH} 5.5$ were hydrolyzed for 1 hour at $63^{\circ} \mathrm{C}$. (standard 
hydrolysis temperature), at $55^{\circ}$, and $40^{\circ} \mathrm{C}$, using various quantities of malt.

The results obtained are summarized in Table III and are shown graphically in Fig. 1.

TABLE III

Effect of Barley Malt Quantity on Corn Amylopectin

Hydrolysis at Various Temperatures (Hydrolysis Time - 1 hour)

HYDROLYSIS TERPERATURE

\begin{tabular}{|c|c|c|c|c|c|}
\hline \multicolumn{2}{|c|}{$63^{\circ} \mathrm{C}}$. & \multicolumn{2}{|c|}{$55^{\circ} \mathrm{C}}$. & \multicolumn{2}{|c|}{$10^{\circ} \mathrm{C}$} \\
\hline $\begin{array}{l}\text { Malt* } \\
\text { Per Cent }\end{array}$ & $\begin{array}{l}\text { Conversion } \\
\text { Per Cent }\end{array}$ & $\begin{array}{c}\text { Malt } \\
\text { Per Cent }\end{array}$ & $\begin{array}{c}\text { Conversion } \\
\text { Per Cent }\end{array}$ & $\begin{array}{c}\text { Malt } \\
\text { Per Cent }\end{array}$ & $\begin{array}{l}\text { Conversion } \\
\text { Per Cent }\end{array}$ \\
\hline $\begin{array}{r}8 \\
11 \\
13 \\
14 \\
22 \\
24 \\
46\end{array}$ & $\begin{array}{l}39.0 \\
61.9 \\
62.7 \\
61.8 \\
63.1 \\
64.3 \\
64.6\end{array}$ & $\begin{array}{r}9 \\
10 \\
12 \\
13 \\
28 \\
65 \\
100\end{array}$ & $\begin{array}{l}67.7 \\
68.3 \\
70.2 \\
73.7 \\
75.0 \\
76.7 \\
78.5\end{array}$ & $\begin{array}{r}9 \\
12 \\
31 \\
46\end{array}$ & $\begin{array}{l}67.1 \\
68.8 \\
67.9 \\
68.2\end{array}$ \\
\hline
\end{tabular}

* Malt Per Cent" is the ratio of whole malt (dry basis) weight to amylopectin weight, expressed as per cent.

The conversion-malt quantity curves are similar in shape for the three hydrolysis temperatures, $63^{\circ} \mathrm{C} ., 55^{\circ} \mathrm{C}$, and $40^{\circ} \mathrm{C}$. For a given malt quantity up to 15 per cent malt, a greater degree, as well as more rapid rate, of hydrolysis is achieved at $55^{\circ} \mathrm{C}$. than at the usual conversion temperature of $63^{\circ} \mathrm{C}$. With an increase in malt quantity beyond 15 per cent, the conversion rate appears to be approximately the same for the three temperatures studied. In general, the 


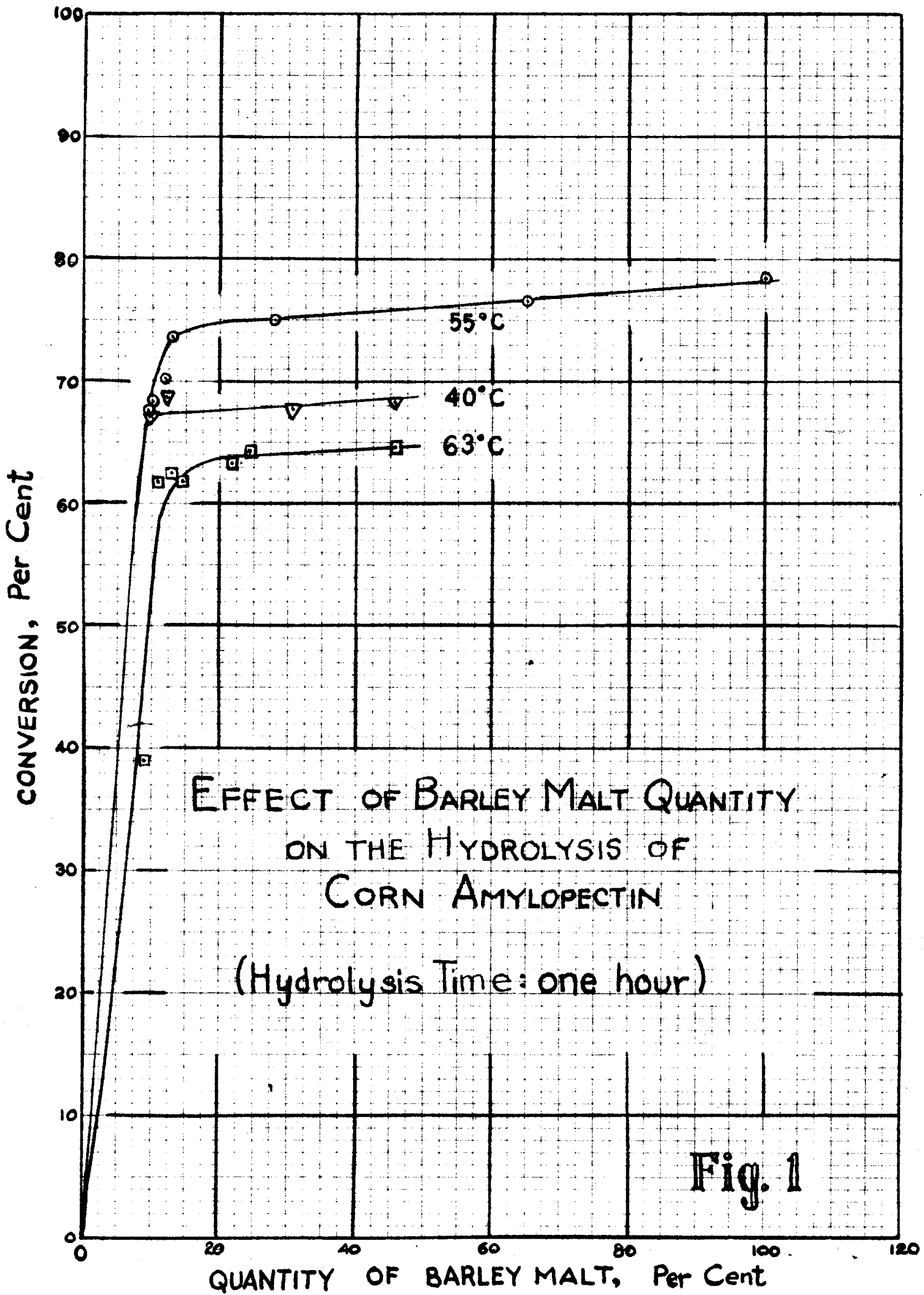


results indicate clearly that at any malt quantity, a greater degree of hydrolysis is achieved at $55^{\circ} \mathrm{C}$. than at $63^{\circ}$ or $40^{\circ}$. In no case was there any significant advantage in using more than 15 per cent malt for a normal conversion.

For a general procedure, for the conversion studies, however, it was desired to find a fairly wide range of malt quantity where slight increase in quantity would have little or no effect on the degree of hydrolysis. This was necessary in order to avoid interference due to changes in degree of conversion because of slight differences in malt quantity. It appeared that an ideal malt quantity range was 20-35 per cent malt. In this range the maximum difference in conversion due to malt quantity was slight (less than $I$ per cent for each of the temperatures studied).

It was also important to determine the effect of concentration of the starch component on the degree and rate of hydrolysis. The concentration of anylose that could be used in hydrolysis studies was definitely limited to a very dilute concentration (less than I per cent) since more concentrated dispersions retrograded very readily. To determine the effect of amylopectin concentration, the concentrated stock amylopectin was buffered at $\mathrm{pH} 5.5$ and diluted to make a 9 per cent amylopectin dispersion. The dilute stock anylopectin was also buffered at pH 5.5 and diluted to make a 1 per cent dispersion. The results of hydrolysis at $55^{\circ} \mathrm{C}$. and for various time periods are show in Table IV. 
Effect of Amylopectin Concentration on the Degree and Rate of Hydrolysis by Barley Malt

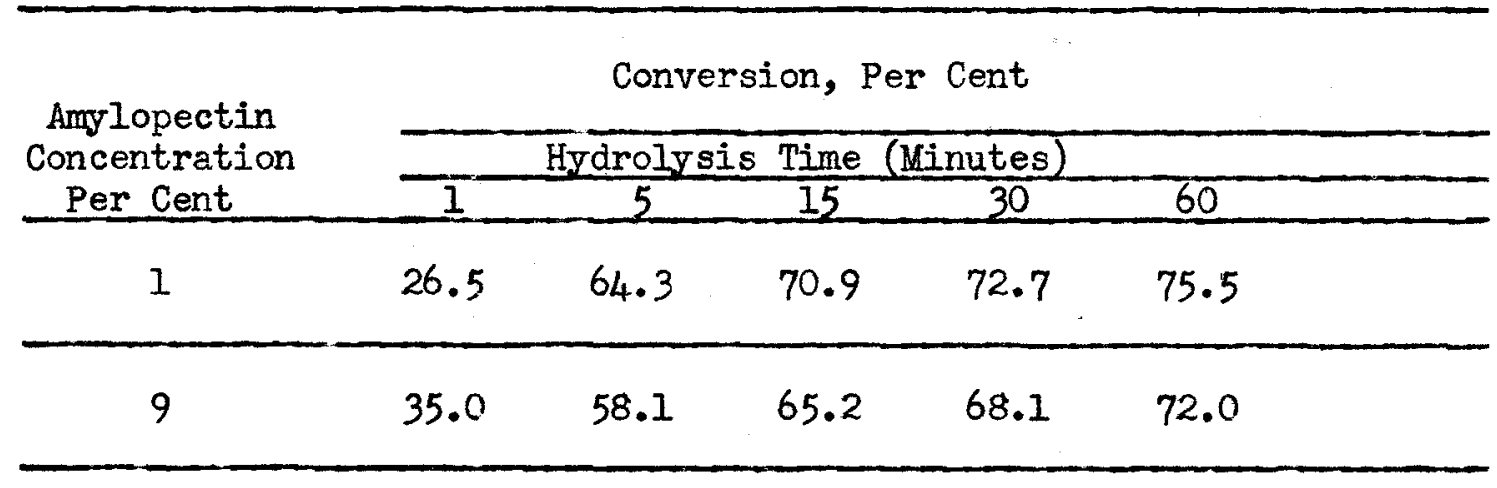

Conversion of the dilute amylopectin is slightly higher than conversion of the concentrated amylopectin, except for the one minute hydrolysis time. The difference in conversion between dilute and concentrated amylopectin decreases with an increase in hydrolysis time; this difference may be due to a greater dispersion of the malt in the dilute amylopectin.

Since there is not a great difference in degree of hydrolysis at different concentrations, the remainder of the hydrolysis studies were made at the low amylopectin concentration ( 1 per cent).

Procedure for Malt Hydrolysis of Amylose and Amylopectin

Dilute stock amylopectin dispersion was used to prepare the I per cent amylopectin dispersion used in most of the hydrolysis work. A portion of the dilute stock amylopectin was adjusted to the desired $\mathrm{pH}$ by the addition of approximately $20 \mathrm{ml}$. of $0.2 \mathrm{M}$ "phosphate buffer I" 
to $1 \mathrm{gm}$. of amylopectin and then diluted to the desired concentration.

Amylose was dispersed in water, buffered and made to a concentration of approximately 0.5 per cent as described under preparation of materials. The amylose was prepared just before use and was not allowed to cool, in order to prevent retrogradation.

For each sample, a 20 or $25 \mathrm{ml}$. portion of the amylose or amylopectin dispersion was pipetted into a 200 or $250 \mathrm{ml}$. volumetric flask. The series of flasks was then placed in a water bath previously adjusted to the desired temperature; after approximately one hour, a measured quantity of malt extract was carefully added to each flask from a quick delivery pipette and the time noted. The samples were shaken frequently after the addition of the malt extract. At the end of the hydrolysis time period (accurately measured), 15-20 ml. of $0.2 \mathrm{~N} \mathrm{NaOH}$ was immediately added to stop the hydrolysis. After shaking, the samples were made to volume at room temperature.

Aliquots were removed from each sample and from the malt extract for the determination of reducing sugar and total sugar by the method of Stiles, Peterson and Fred (39). In the determination of total sugars, the sample was hydrolyzed with an equivalent volume of $1.38 \mathrm{~N} \mathrm{HCl}$ by boiling for 2.5 hours (37) and then neutralized and the total sugar, calculated as glucose, determined. In all sugar determinations duplicate samples were run and all samples were corrected for sugar derived from the malt.

In order to correlate the observed titration difference for 
the volume of sodium thiosulfate required for the blank and for a sample, with the quantity of sugar in the sample, it was necessary to run a series of samples containing known quantities of pure maltose and another series containing known quantities of glucose. The table presented by Stiles, Peterson and Fred (3) for calculating glucose was found to be inaccurate in the lower and upper range of titration differences. The observed titration difference corresponding to the known quantity of maltose or glucose present in a $5 \mathrm{ml}$. sample (the quantity taken for analysis) are tabulated in Table $\nabla$. When the data was plotted it was found that the relation between sugar quantity and titration difference could be represented by a straight line with a slight bend at either end. Sugar values for a series of titration differences were calculated from the data by the method of least squares. The calculated values are presented in Table I. 


\section{TABLE V}

Relation between Thiosulfate Titration Difference and Quantity of Maltose and Glucose

\begin{tabular}{cccc}
\hline $\begin{array}{c}\text { Maltose } \\
\text { mg. }\end{array}$ & $\begin{array}{c}\text { Thiosulfate } \\
\text { Titration } \\
\text { Difference } \\
\text { ml.* }\end{array}$ & $\begin{array}{c}\text { Glucose } \\
\text { mg. }\end{array}$ & $\begin{array}{c}\text { Thiosulfate } \\
\text { Titration } \\
\text { Difference } \\
\text { ml.* }\end{array}$ \\
\hline 0.400 & 0.75 & 0.075 & - \\
0.600 & 1.33 & 0.125 & 0.19 \\
0.800 & 2.08 & 0.250 & 1.07 \\
1.000 & 2.79 & 0.375 & 1.92 \\
1.400 & 4.14 & 0.500 & 2.89 \\
2.000 & 6.49 & 0.625 & 3.84 \\
2.400 & 7.98 & 0.750 & 4.57 \\
2.800 & 9.69 & 1.125 & 7.73 \\
3.000 & 10.24 & 1.250 & 8.67 \\
3.400 & 12.01 & 1.375 & 9.82 \\
3.800 & 13.56 & 1.500 & 10.87 \\
4.000 & 14.66 & 1.625 & 11.87 \\
4.400 & 15.73 & 2.000 & 14.63 \\
4.800 & 17.46 & 2.250 & 16.47 \\
5.000 & 17.95 & 2.375 & 17.13 \\
& & & \\
\hline
\end{tabular}

* Each value given is an average of three determinations for maltose and two determinations for glucose. The maltose determinations were made by Dr. R. E. Moser, member of the Seagram Research Laboratory. 
TABLE V1

MTCRO SUGAR TABLE

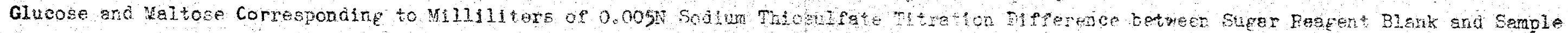

\begin{tabular}{|c|c|c|c|c|c|c|c|c|c|c|c|c|c|c|}
\hline $\begin{array}{c}\text { Titration } \\
\text { Difference } \\
\text { nh. }\end{array}$ & $\begin{array}{l}\text { Clucose } \\
\text { me } \\
\end{array}$ & $\begin{array}{c}m=2 t 0 \mathrm{se} \\
\mathrm{me}\end{array}$ & $\begin{array}{c}\text { Titration } \\
\text { Dipference } \\
\text { mi. }\end{array}$ & $\begin{array}{c}\text { Glucose } \\
\mathrm{me} \\
\end{array}$ & $\begin{array}{c}\text { Maltose } \\
\text { tre } \\
\end{array}$ & $\begin{array}{c}\text { Titration } \\
\text { Difference } \\
\text { mi. }\end{array}$ & $\begin{array}{c}\text { Olucose } \\
m p\end{array}$ & $\begin{array}{c}\text { Aeitese } \\
\mathrm{me}\end{array}$ & $\begin{array}{l}\text { Mitretion } \\
\text { Pifereice } \\
m\end{array}$ & $\begin{array}{c}\text { onoose } \\
\text { mes } \\
\end{array}$ & $\begin{array}{c}\text { Matoge } \\
m g .\end{array}$ & $\begin{array}{c}\text { Tipraton } \\
\text { Liprorence } \\
\text { ni. }\end{array}$ & $\begin{array}{c}\text { Gucose } \\
\text { meo }\end{array}$ & $\begin{array}{c}\text { Mentose } \\
\text { me } \\
\end{array}$ \\
\hline $\begin{array}{l}2.0 \\
.2 \\
.2 \\
.3 \\
.4 \\
.5 \\
6 \\
.7 \\
.8 \\
0\end{array}$ & $\begin{array}{r}0.378 \\
.392 \\
.405 \\
.418 \\
.438 \\
.446 \\
.460 \\
.474 \\
.488 \\
501\end{array}$ & $\begin{array}{r}0.777 \\
.806 \\
.835 \\
.864 \\
.893 \\
.922 \\
.951 \\
.980 \\
1.009 \\
.038\end{array}$ & $\begin{array}{l}5.0 \\
.1 \\
.2 \\
.3 \\
.4 \\
.5 \\
.6 \\
.7 \\
.8 \\
.9\end{array}$ & $\begin{array}{l}0.783 \\
.795 \\
.807 \\
.820 \\
.822 \\
.844 \\
.857 \\
.869 \\
.381 \\
.894\end{array}$ & $\begin{array}{l}1.615 \\
.640 \\
.666 \\
.692 \\
.717 \\
.743 \\
.769 \\
.794 \\
.820 \\
.846\end{array}$ & $\begin{array}{r}8.0 \\
.1 \\
.2 \\
.3 \\
.4 \\
.8 \\
6 \\
.7 \\
.8 \\
.9\end{array}$ & $\begin{array}{l}.85 \\
.165 \\
.179 \\
.190 \\
.802 \\
215 \\
27 \\
239 \\
252 \\
24\end{array}$ & $\begin{array}{r}2.38 \\
.411 \\
046 \\
462 \\
46 \\
53 \\
523 \\
565 \\
560 \\
636\end{array}$ & $\begin{array}{r}11.0 \\
1 \\
2 \\
2 \\
2 \\
0 \\
3 \\
0 \\
3 \\
2 \\
9\end{array}$ & 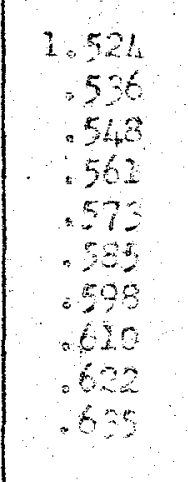 & $\begin{array}{r}2.255 \\
.131 \\
.205 \\
.252 \\
.25 \\
.29 \\
.309 \\
.395 \\
.38 \\
.386\end{array}$ & 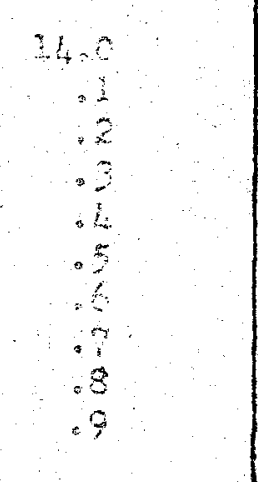 & $\begin{array}{r}3.905 \\
.918 \\
.991 \\
.944 \\
.956 \\
.969 \\
.982 \\
.995 \\
2.007 \\
.020\end{array}$ & $\begin{array}{l}0.725 \\
.051 \\
.977 \\
4.002 \\
.028 \\
.05 \\
.079 \\
.105 \\
.01 \\
.156\end{array}$ \\
\hline $\begin{array}{l}3.0 \\
.1 \\
.2 \\
.3 \\
.4 \\
.5 \\
.6 \\
.7 \\
.8 \\
.9\end{array}$ & $\begin{array}{l}0.515 \\
.529 \\
.542 \\
.556 \\
.570 \\
.583 \\
.595 \\
.611 \\
.624 \\
.638\end{array}$ & $\begin{array}{l}1.067 \\
.096 \\
.126 \\
.155 \\
.184 \\
.213 \\
.242 \\
.271 \\
.300 \\
329\end{array}$ & $\begin{array}{l}6.0 \\
.2 \\
.2 \\
.3 \\
.4 \\
.5 \\
.6 \\
.7 \\
.8 \\
0\end{array}$ & $\begin{array}{l}0.906 \\
.918 \\
.931 \\
.043 \\
.955 \\
.963 \\
.980 \\
.992 \\
.005 \\
.017\end{array}$ & $\begin{array}{l}1.871 \\
.897 \\
.023 \\
.948 \\
.974 \\
2.000 \\
.025 \\
.051 \\
.077 \\
.103\end{array}$ & $\begin{array}{l}9.0 \\
8 \\
02 \\
.3 \\
.4 \\
.3 \\
.6 \\
.7 \\
.8 \\
.9\end{array}$ & 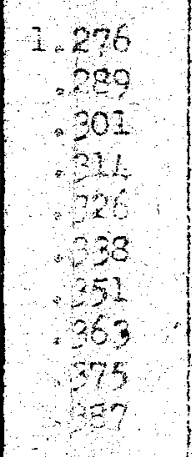 & $\begin{array}{r}2.642 \\
647 \\
69 \\
.719 \\
74 \\
.770 \\
.796 \\
.821 \\
.847 \\
.873\end{array}$ & $\begin{array}{r}12.0 \\
1 \\
2 \\
.3 \\
4 \\
5 \\
6 \\
7 \\
6\end{array}$ & 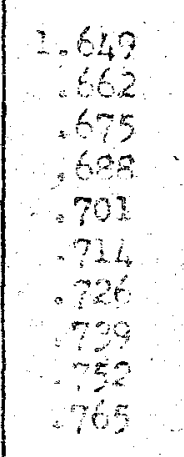 & 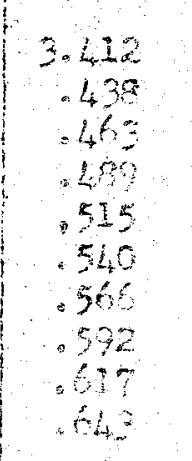 & $\begin{array}{r}15.0 \\
.3 \\
.2 \\
02 \\
.4 \\
5 \\
.6 \\
7 \\
8 \\
.9\end{array}$ & $\begin{array}{l}2.03 \\
.046 \\
.059 \\
.071 \\
0.08 \\
.096 \\
.110 \\
.122 \\
.195 \\
.348\end{array}$ & 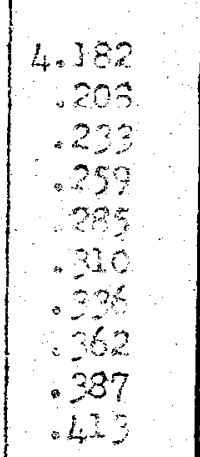 \\
\hline $\begin{array}{l}4.0 \\
.1 \\
.2 \\
.3 \\
.4 \\
.5 \\
.6 \\
7 \\
.8 \\
.8\end{array}$ & $\begin{array}{r}0.652 \\
.666 \\
.679 \\
.693 \\
.708 \\
.723 \\
.793 \\
.745 \\
.758 \\
.770\end{array}$ & $\begin{array}{r}1.353 \\
.381 \\
.409 \\
.425 \\
.482 \\
486 \\
.512 \\
.533 \\
.563 \\
.589\end{array}$ & $\begin{array}{r}7.0 \\
1 \\
.2 \\
.3 \\
.4 \\
.5 \\
.6 \\
.7 \\
.6 \\
.9\end{array}$ & $\begin{array}{r}1.030 \\
.042 \\
.053 \\
.067 \\
.079 \\
.021 \\
.104 \\
.116 \\
.128 \\
.141\end{array}$ & $\begin{array}{r}2.128 \\
.154 \\
.180 \\
.205 \\
.231 \\
.25 \\
.28 \\
.208 \\
.231 \\
.359\end{array}$ & $\begin{array}{r}10.5 \\
7 \\
2 \\
0 \\
6 \\
5 \\
6 \\
7 \\
6 \\
0\end{array}$ & $\begin{array}{r}1.400 \\
.12 \\
.25 \\
27 \\
48 \\
474 \\
486 \\
499 \\
54\end{array}$ & $\begin{array}{r}2.890 \\
921 \\
950 \\
975 \\
2003 \\
027 \\
.052 \\
078 \\
.104 \\
.129\end{array}$ & $\begin{array}{r}1.0 \\
.2 \\
.2 \\
03 \\
4 \\
5 \\
5 \\
7 \\
0 \\
0 \\
9\end{array}$ & $\begin{array}{r}.777 \\
.790 \\
.807 \\
.816 \\
829 \\
.841 \\
.854 \\
.807 \\
.880 \\
.892\end{array}$ & $\begin{array}{r}2.659 \\
.694 \\
.720 \\
746 \\
.77 \\
797 \\
.823 \\
.248 \\
.874 \\
.900\end{array}$ & $\begin{array}{r}160 \\
1 \\
.2 \\
-2 \\
4 \\
5 \\
6 \\
-7 \\
9 \\
9\end{array}$ & $\begin{array}{r}2.122 \\
.274 \\
.180 \\
299 \\
212 \\
.225 \\
.237 \\
250 \\
280 \\
0.276\end{array}$ & $\begin{array}{r}4.40 \\
168 \\
.59 \\
.516 \\
.542 \\
.597 \\
593 \\
.619 \\
.44 \\
.670\end{array}$ \\
\hline
\end{tabular}


Calculation Methods:

\section{Malt Quantity}

The quantity of barley malt used is expressed as "per cent malt based on amylopectin"; this quantity is represented by the term:

$$
\frac{100 \mathrm{MV}}{\mathrm{A}}
$$

where $M=$ weight (gm.) of whole malt (dry basis) per 1.0 ml. of malt-water mixture

$\mathrm{V}=$ volume (ml.) of malt-water mixture used per unit volume of amylopectin-water mixture.

$A=$ weight (gm.) of amylopectin present in the volume of amylopectin-water mixture to which the volume $V$ of malt extract was added.

For example, if $0.8 \mathrm{ml}$. of a 15.8 per cent malt extract is used to hydrolyze $20 \mathrm{ml}$. of a 1.00 per cent amylopectin dispersion (equal to $0.2 \mathrm{~g}$. amylopectin) then:

$$
\frac{100 \times 0.158 \times 0.8}{0.2}=63.2 \text { per cent malt (based on amylo- }
$$

Actually, the malt quantity represents the ratio of whole malt to amylopectin, expressed as per cent.

\section{Degree of Hydrolysis}

The degree of hydrolysis of amylopectin by malt is expressed as "per cent conversion" and is represented by the term: 
Rerucing sugar (calculated as maltose) $\times 105.2$

Initial amylopectin (calculated as glucose)

where

1. "Reducing sugar" is the amount of reducing substance calculated as maltose present at the end of the hydrolysis.

2. "Initial amylopectin" is the amount of glucose resulting from the acid hydrolysis of the amylopectin initially present.

3. The value 105.2 is the ratio of the molecular weight of two molecules of glucose and one molecule of maltose times 100 . 


\section{Experimental Results and Discussion}

It has been reported in the literature that the amylose fraction of starch is practically completely hydrolyzed and the amylopectin fraction approximately 60 per cent hydrolyzed by barley malt amylases. It was desired in this study to determine the degree of hydrolysis of amylose and amylopectin under standard conditions of hydrolysis as employed in distillery practice, that is, at a temperature of $63^{\circ} \mathrm{C}$. and a $\mathrm{pH}$ of 5.5 .

Hydrolysis of Amylose and Amylopectin Under Standard Conditions

A one per cent amylopectin dispersion and \& 0.5 per cent amylose dispersion were hydrolyzed with barley malt ( 30 per cent based on the weight of starch component) under standard conditions $\left(63^{\circ} \mathrm{C}\right.$. and $\left.\mathrm{pH} 5.5\right)$ for various periods of time. The results are shown in Table VII and are shown graphically in Fig. 2.

\section{TABLE VII}

Hydrolysis of Corn Amylose and Amylopectin at $63^{\circ} \mathrm{C}$. and pH 5.5

\begin{tabular}{ccccc}
\hline \multirow{2}{*}{\begin{tabular}{c} 
Hydrolysis $\begin{array}{c}\text { Conversion, } \\
\text { Time, } \\
\text { Minutes }\end{array}$ \\
\cline { 2 - 5 }
\end{tabular}} & \multicolumn{3}{c}{ Per Cent } \\
\cline { 2 - 5 } & Run 1 & Run 2 & Run 3 & Run 4 \\
\hline 5 & -5 & 82.8 & 43.9 & 50.0 \\
15 & 93.9 & 89.8 & 59.1 & 58.4 \\
30 & 99.3 & 92.8 & 61.9 & 59.6 \\
60 & 99.3 & 92.9 & 61.9 & 62.7 \\
120 & 99.3 & 94.3 & -6 & 63.3 \\
180 & 102.4 & - & 63.9 & 64.3 \\
\hline
\end{tabular}




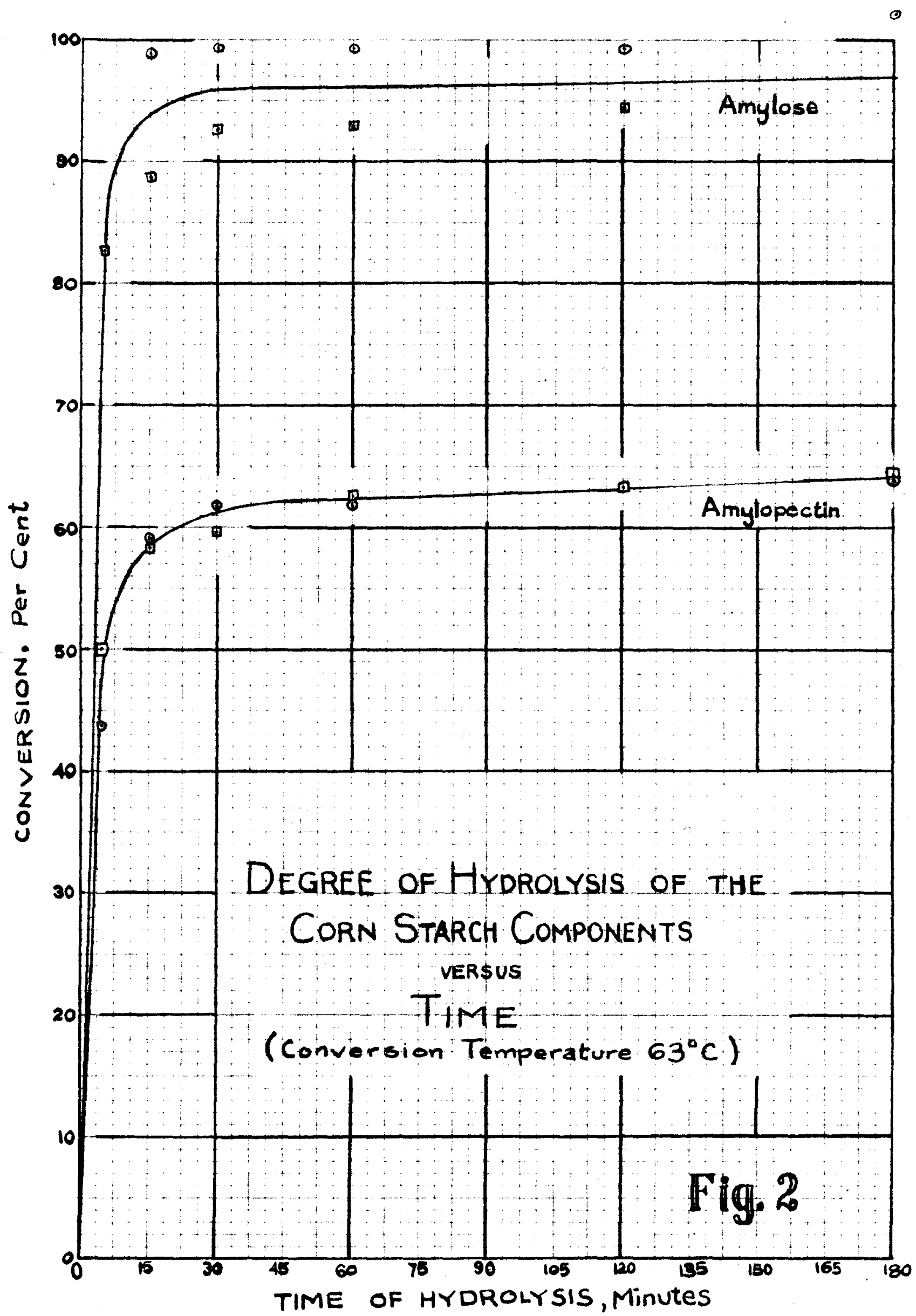


As may be readily seen from the graph (Fig. 2) the rate of conversion of starch components at $63^{\circ} \mathrm{C}$. was very rapid for the first 5 minutes for amylose and for the first 10 minutes for amylopectin. After 15 minutes, there was only a relatively slight increase in conversion. Amylose was almost completely hydrolyzed to reducing sugars at the end of 30 minutes whereas the amylopectin was only approximateIy 62 per cent converted at this time. Conversion at the end of 3 hours was only slightly higher for both the amylose and amylopectin.

These data are very significant in that they show that the degree of conversion at $630 \mathrm{C}$. was almost as great at 5-10 minutes as at long conversion times ( 3 hours). It is interesting to note that whereas the initial rate of conversion of amylose was approximately twice that of amylopectin during the early stage of conversion, after the "leveling off" period the rates became approximately the same. The conversion before and after the "leveling off" period was linear with respect to time. Secondl $y$, the data clearly indicate that the main constituent of grain starches, amylopectin was only partially (approximately 64 per cent) converted to fermentable sugar previous to fermentation by the malt conversion procecure as emploted in distillery practice.

The difference between the values obtained in Runs I and II for amylose were probably due to slight retrogradation of the amylose before hydrolysis in Bun II. Even at the lov amylose concentration (0.5 per cent) employed in this study, some retrogradation may have occurred. (Retrograded anylose is resistant to malt hydrolysis.) 
Studies of Factors Affecting Malt Hydrolysis of Corn Anylopectin

Since the data indicate that the amylose frection was quickIy and approximately completely hydrolyzed to reducing sugars, it was decided to discontinue experimental work on this fraction and to study the effect of various factors influencing the hydrolysis of the fraction that is normally incompletely hydrolyzed - that is, the amylopectin fraction.

It is well known that enzyne activity is influenced by a large number of factors, the most important of which are: (a) nature and specific action of the enzyme, (b) temperature and time of holding at the tempersture, (c) hydrogen ion concentration, (d) relative concentrations of the enzme and the substrate, (e) presence of impurities which may either accelerete, stabilize or inhibit enzyme action.

In order to determine quantitatively the effect of these verious factors on the action of whole malt amylases on amylopectin and to determine optimum conditions for the action of the malt amylases, amylopectin was hydrolyzed under various conditions of temperature, time, and hydrogen ion concentration. Studies vere also made on the effect of extracting malt under various conditions of temperature, $\mathrm{pH}$, etc. on the power of the malt to hydrolyze amylopectin.

Fffect of Temperature on Hrdrolysis of Amylopectin by Barley Malt:

The optimum tompercture for enzyme action under a pertionlar set of woring conditions is the point of balance between the 
accolerating effect of temperature upon a catalyzed reaction and the destructive effect of heat upon the enzyme. This optimum temperature varies with the time of reaction, $\mathrm{pH}$ and impurities present. In the present study it was desired to study the effect of temperature and time of holding (at constant tempercture) on the hydrolytic power of malt amylases on corn amylopectin.

\section{TABLE VIII}

Effect of Hydrolysis Time and Tempcreture on the Decree of Hydrolysis of Corn Amyzopectin*

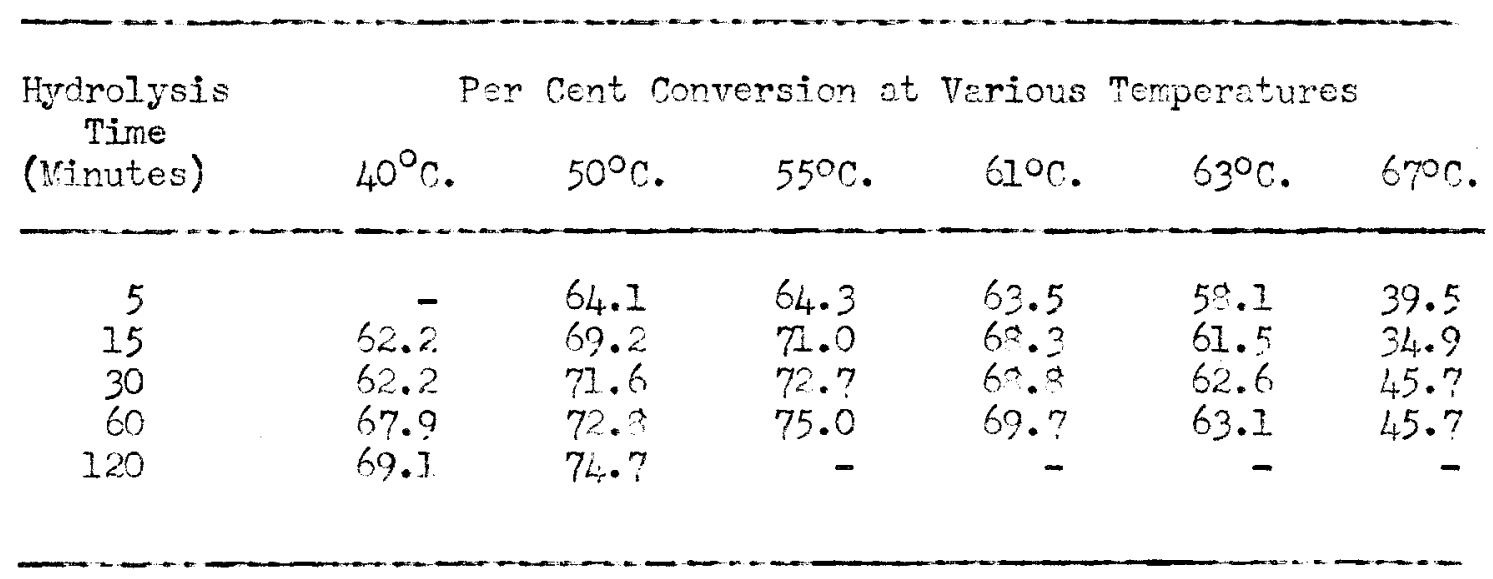

*helt quantity was $22+31$ per cent besed on Amylopectin; pH was 5.5. 


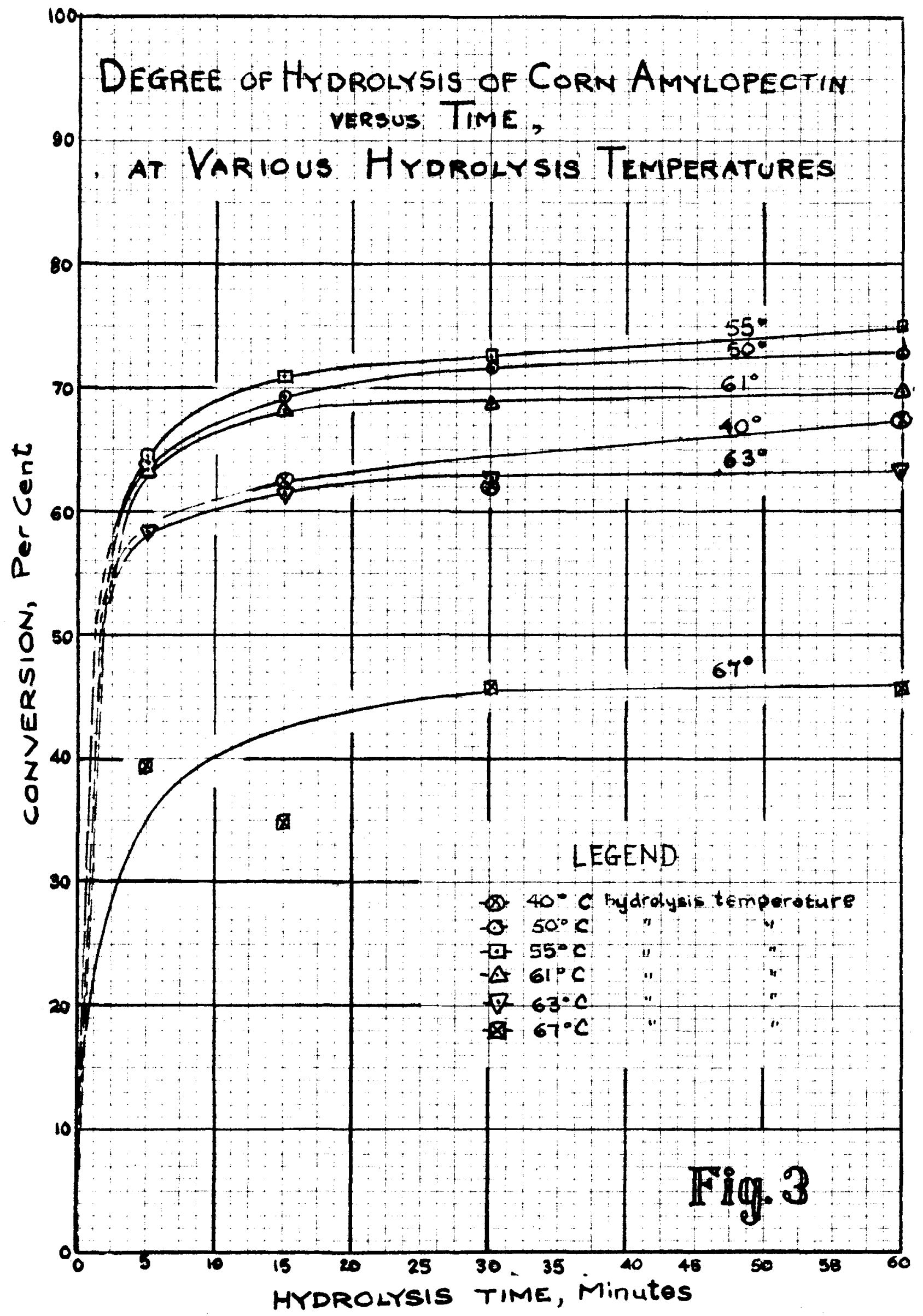




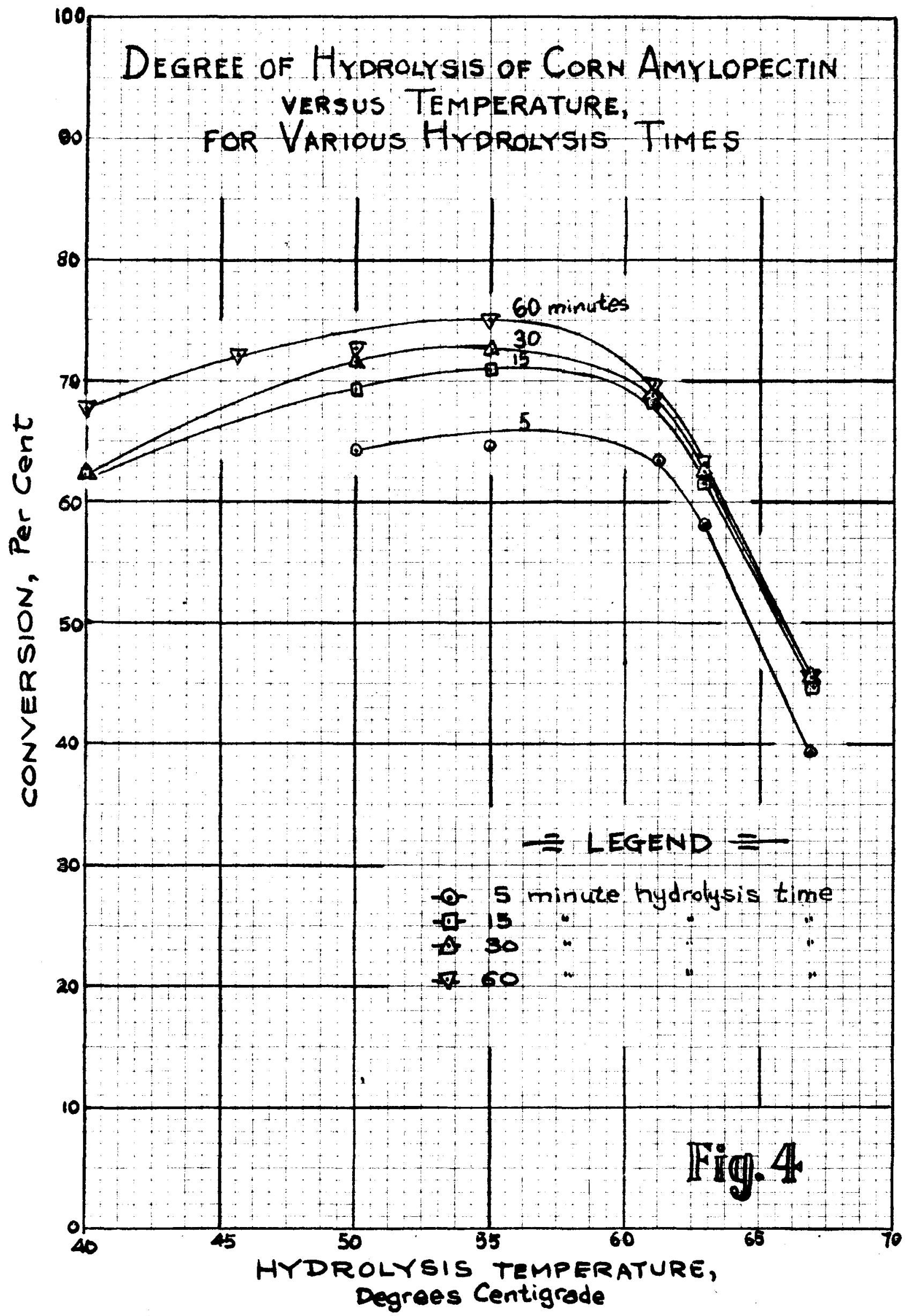


The date as plotted in Fig. 3 indicated that for any hydrolysis temperature between $40^{\circ}$ and $63^{\circ} \mathrm{C}$, the rate of hydrolysis for the first three to five minutes wes extrenely rapid; during this period annroximetely 55 per cent of the amylopectin was converted to reducing sugar. The reaction after the first five minutes was very slow, probably because of some configuration in the amylopectin stmeture that tends to resist further amylase action. The data also shoved that a significantly higher degree of hydrolysis was attained with a hydrolysis temperature of $55^{\circ} \mathrm{C}$. than the usual tempereture used in distillery prectice, $63^{\circ} \mathrm{C}$. From Fig. L, it is shorm that at the latter temperature, heat inactivation of the amylases is definite$l y$ in evidence, particularly for hydrolysis time periods in excess of five minutes. It is strongly probable that if the malt quantity were reduced (an excess was used in this experiment) to the normal amount used in distillery practice, the inactivation at temperctures above $55^{\circ} \mathrm{C}$. would be even more pronounced. The relatively high degree of hydrolysjs at lower tempercture $\left(40^{\circ} \mathrm{C}\right.$.) indicated thet if a temperature of alproximetel $\mathrm{y}^{\circ} \mathrm{C}$. is user during the hydrolysis step, further hydrolysis during fermentation should be easily achieved, perticularly since the $55^{\circ}$ hydrolysis tempereture should leave more amylase available to act during fermentation than a higher hydrolysis temperature.

The conversion-tempercture curves shom in Fie. 4 indicated a gredual rise in conversion with an increase in temperature until an apporent optimum renge wes reached, $53^{\circ}-570 \mathrm{C}$. This rang is apparently 
ع point of balance between the activation and inactivation action of heat on the enzymes. With hydrolysis temperatures in excess of $57^{\circ} \mathrm{C}$. the degree of hydrolysis decreased rapidly with an increase in temperature, possibly due to the denaturation of the amylase protein by heat.

Effect of $\mathrm{pH}$ on the malt hydrolysis of Amylopectin:

The effect of hydrogen ion concentration on the degree of hydrolysis by barley malt was determined using three different buffer solutions. The preparation of the buffers is described under "preparation of Materials". The "Phosphate I" was a monophosphate-diphosphate system (34); "Phosphate II" was made up of citric acid and disodium hydrogen phosphate and functions in the same buffer region covered by the two buffer systems: phosphoric acid-monophosphate and monophosphatediphosphate (1). The third buffer was a phthalate buffer (2). The malt quantity used was varied for each of the phosphate buffers.

The results are summarized in Table IX, data for the one hour hydrolysis are presented in graphical form in Fig. 5. 
TABLE IX

Effect of $\mathrm{pH}$ on the Hydrolysis of Com Amylopectin by Barley Malt

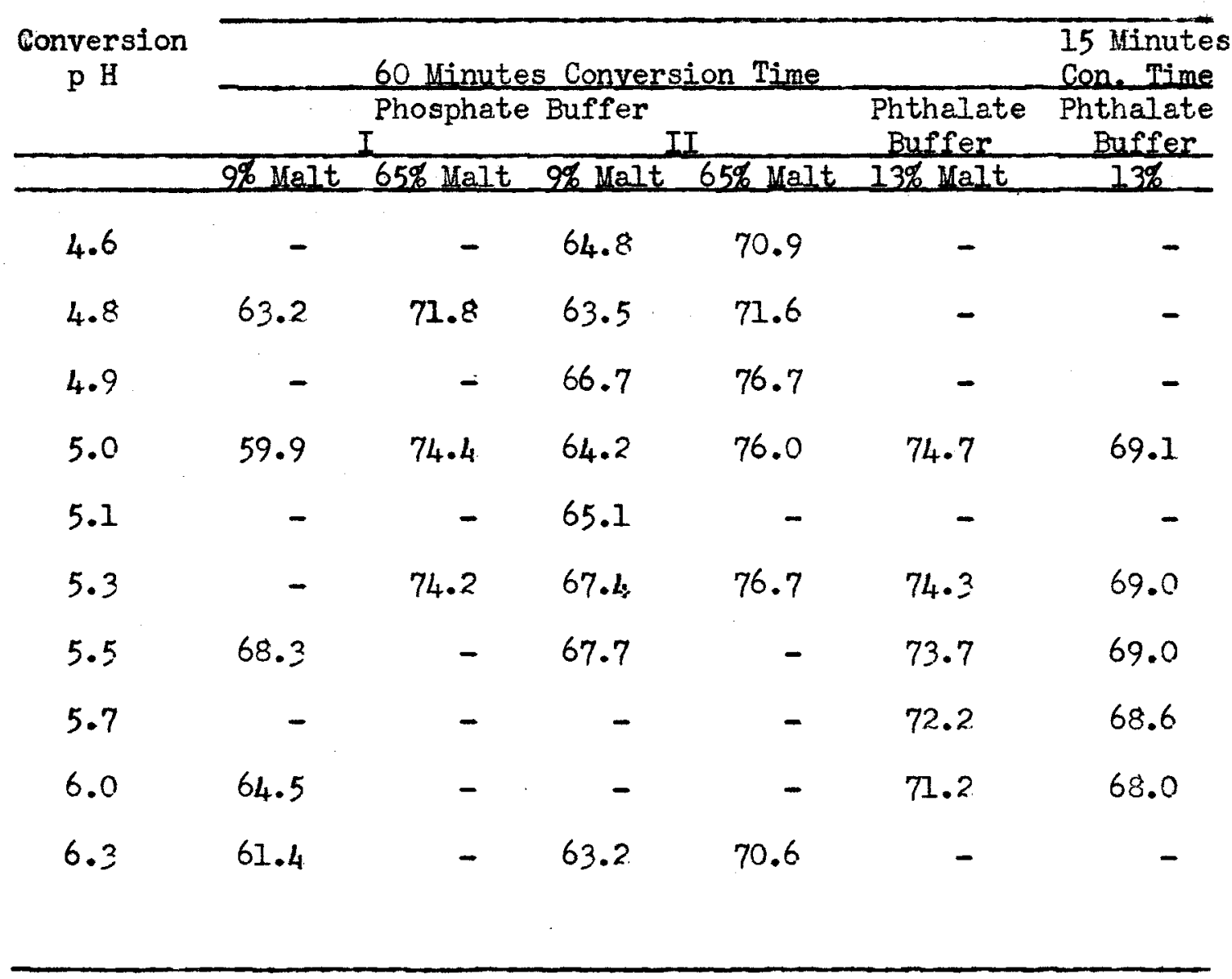




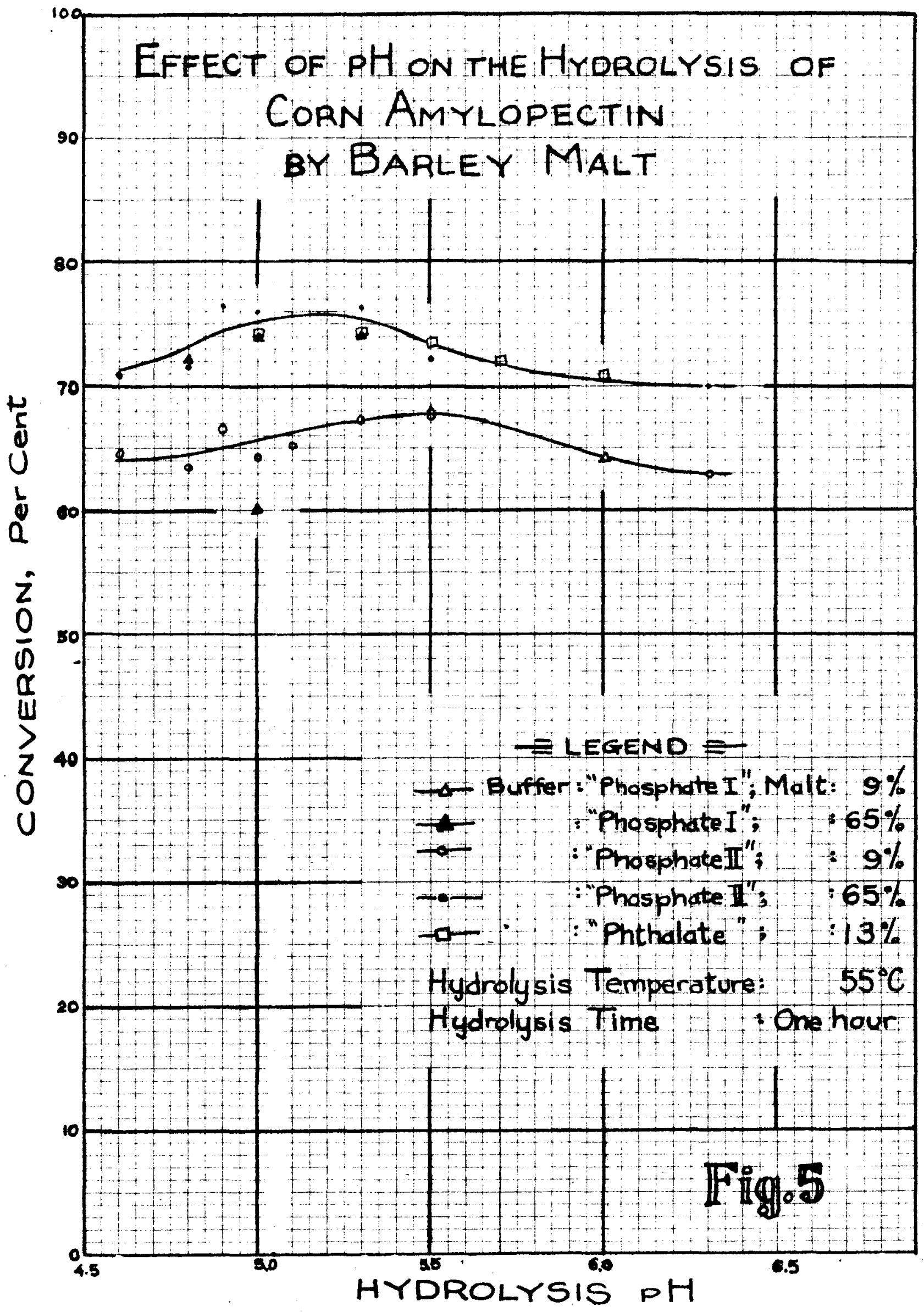


Conversions conducted at $\mathrm{pH}$ values in the range studied ( $\mathrm{pH}$ 4.6-6.3) were not greatly affected by changes in $\mathrm{pH}$. With a large excess of malt ( 65 per cent) the optimum $\mathrm{pH}$ range for the conversion was $5.0-5.3$; with a relatively low quantity of malt, the optimum $\mathrm{pH}$ range was slightly higher, pH 5.3-5.6. These values were indicated for both phosphate buffers. The conversion curve using phthalate buffer and 13 per cent malt practically coincided with the phosphate buffer -65 per cent malt conversion curve.

Since pH is known to have a strong effect on enzyme action, it seems surprising that the effective pH range was so great. However, the malt contains both alpha- and beta-amylase, each of which has different optimum $\mathrm{pH}$ values. The optimum $\mathrm{pH}$ range indicated in the graph is probably a value at which both of the amyleses may act.

It is difficult to interpret $\mathrm{pH}$ data in terms of optimum: this is because operating conditions must determine the optimum pH. The apparent optimum $\mathrm{pH}$ for a reaction is a compromise between a stability optimum and an activity optimum. In general, the $\mathrm{pH}$ optimum will depend on the temperature and duration of the reaction and various other factors.

Effect of Ratio of Barley Malt to Amylopectin on the Hydrolysis of the Amylopectin

The effect of malt quantity (based on amylopectin) on the degree of hydrolysis at $55^{\circ} \mathrm{C}$. and for various periods of time is indicated by the data tabulated in Table $X$ and show graphically in 
Fig. 6. To show more clearly the effect of malt quantity in the critical range, points on the hydrolysis - malt quantity curves coinciding with malt quantities of $5,10,12.5,15,20$, and 25 per cent were replotted and are presented in Fig. 7.

TABLE X

Effect of Malt Quantity on Hydrolysis of Corm Amylopectin for Various Time Periods at $55^{\circ} \mathrm{C}$.

Hydrolysis Time (Minutes)

\begin{tabular}{|c|c|c|c|c|c|c|c|c|c|}
\hline \multicolumn{2}{|r|}{1} & \multicolumn{2}{|r|}{5} & \multicolumn{2}{|r|}{15} & \multicolumn{3}{|c|}{30} & 60 \\
\hline $\begin{array}{c}\text { Malt } \\
\% \\
\end{array}$ & $\begin{array}{l}\text { Conver- } \\
\text { sion \& }\end{array}$ & $\begin{array}{c}\text { Malt } \\
\%\end{array}$ & $\begin{array}{l}\text { Conver- } \\
\text { sion } \%\end{array}$ & $\begin{array}{c}\text { Malt } \\
\%\end{array}$ & $\begin{array}{l}\text { Conver- } \\
\text { sion \% }\end{array}$ & $\begin{array}{c}\text { Malt } \\
\%\end{array}$ & $\begin{array}{l}\text { Conver- } \\
\text { sion } \%\end{array}$ & $\begin{array}{c}\mathrm{Malt} \\
\%\end{array}$ & $\begin{array}{l}\text { Conver- } \\
\text { sion } 8\end{array}$ \\
\hline 14 & 10.5 & 12 & 32.4 & 10 & 65.4 & 11 & 61.9 & 9 & 67.7 \\
\hline 28 & 24.5 & 14 & 47.4 & 12 & 63.9 & 12 & 67.2 & 10 & 68.3 \\
\hline 35 & 25.8 & 25 & 65.9 & 13 & 69.0 & 28 & 72.7 & 12 & 70.2 \\
\hline 70 & 51.8 & 28 & $64 \cdot 3$ & 25 & 70.7 & 100 & 79.2 & 22 & 72.8 \\
\hline 100 & 64.2 & 50 & 71.5 & 28 & 70.8 & & & 28 & 75.0 \\
\hline 102 & 56.5 & 65 & 68.6 & 28 & 71.1 & & & 65 & 72.3 \\
\hline 105 & 60.5 & 65 & 70.7 & 50 & 74.2 & & & 65 & 76.7 \\
\hline 140 & 62.5 & 65 & 69.0 & 100 & 78.1 & & & 65 & 76.8 \\
\hline 162 & 71.0 & 75 & 73.0 & 150 & 80.2 & & & 100 & 78.5 \\
\hline 280 & 55.3 & 100 & 70.7 & & & & & & \\
\hline & & 200 & 68.6 & & & & & & \\
\hline
\end{tabular}




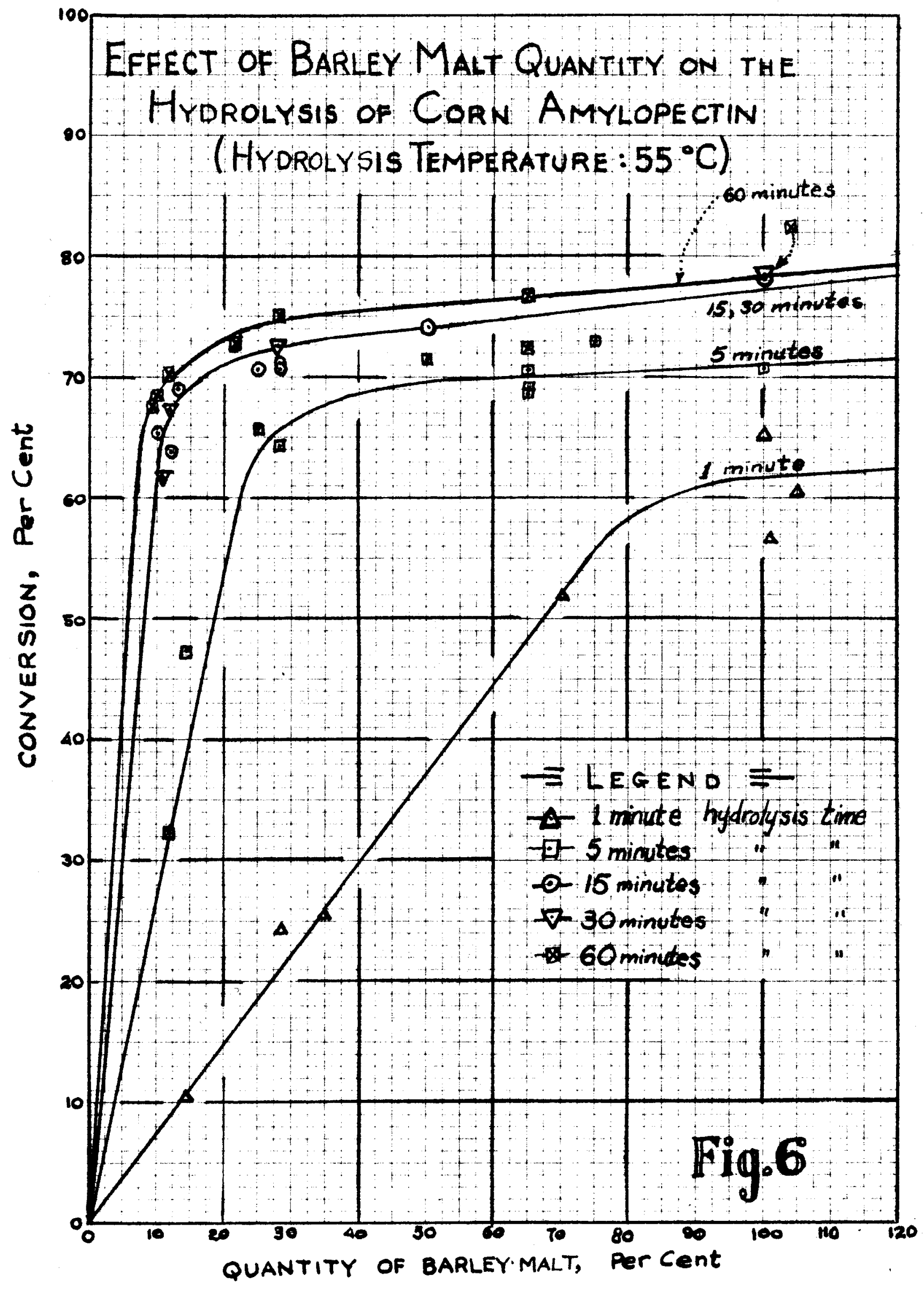




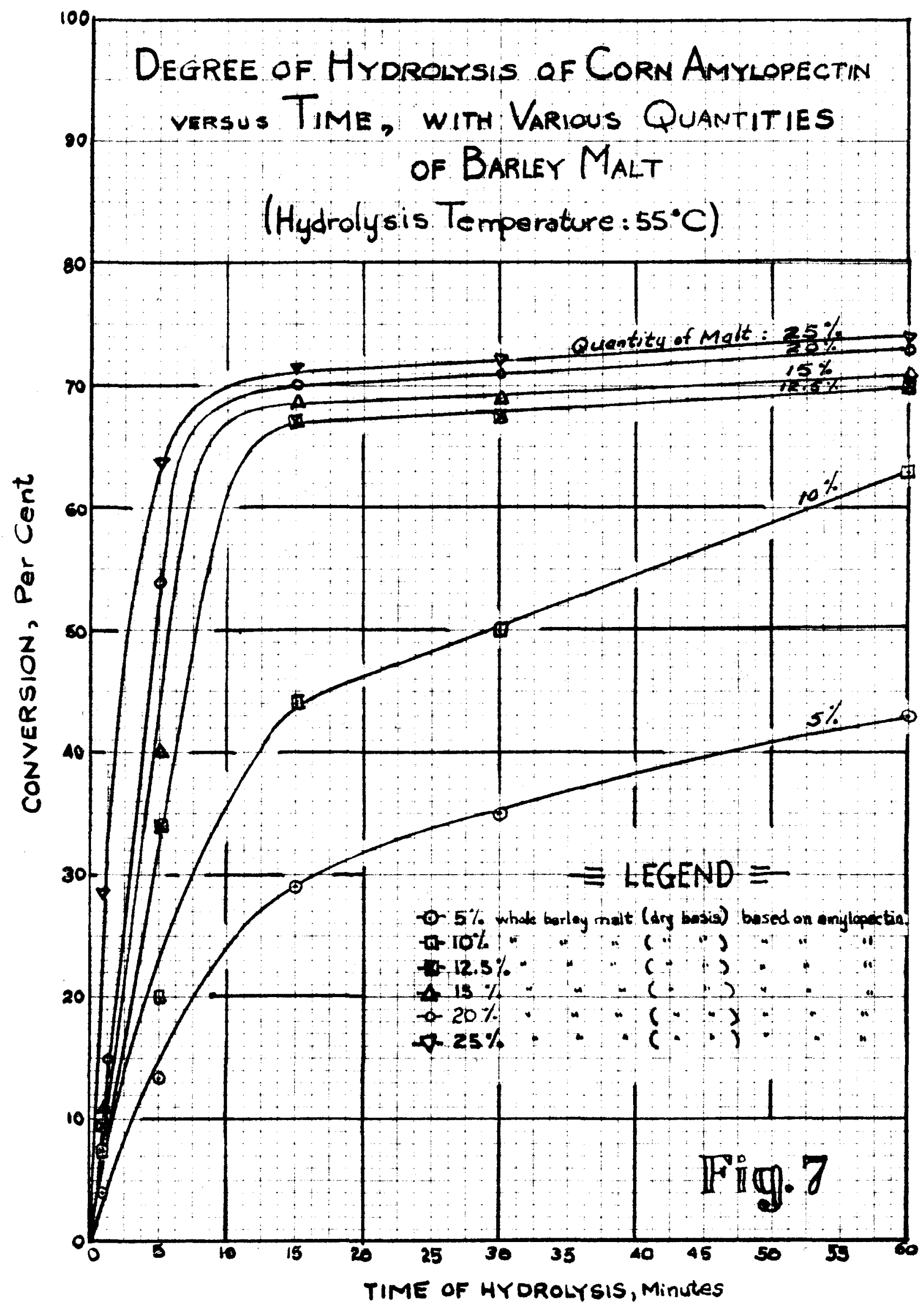


The results show in Fig. 6 indicated that the greater the hydrolysis time (at $55^{\circ} \mathrm{C}$.), the less malt was required to produce a given degree of conversion. However, an increase in hydrolysis time after the first 15 minutes gave only very slightly higher conversion provided the malt quantity was in excess of 10 per cent.

In distillery practice where it is desired to use as small a quantity of malt and allow as short a conversion time as possible, the ideal combination for malt hydrolysis (using the malt sample on which these studies were made) would seem to be approximately 12.5 per cent malt (based on amylopectin) and a conversion time of 15 minutes. Obviously, further studies on different barley malts would be necessary before any general rule could be established. The data presented here are useful in showing in a general way the effect of malt quantity and in showing that there is practically no advantage in hydrolyzing amylopectin in excess of 15 minutes.

Not show on the graphs, but indicated by the data in Table $X$, relatively massive quantities of malt (in excess of 200 per cent) bring about a significant decrease in degree of hydrolysis. This decrease may be due to an inhibitory effect of an increased quantity of maltose, derived from the malt extract, in the reaction mixture (a malt quantity of 200 per cent would be equivalent to approximately 40 per cent maltose added to the amylopectin to be hydrolyzed. 
Effect of various malt extraction procedures on the power of the Malt to hydrolyze amylopectin:

Data on the effect of amylopectin hydrolysis of (I) $\mathrm{pH}$ and temperature during the malt extraction process and (II) the storage time of the extract on hydrolysis are summarized in Table XI and are shown graphically in Fig. \&. The malt extracts were prepared as described under "Preparation of Materials Special Malt Extract $A^{\prime \prime}$. Standard hydrolysis procedure at $55^{\circ} \mathrm{C}$. and $\mathrm{pH} 5.5$ was employed.

\section{TABLE XI}

Effect of (I) pH and Temperature of the Malt Extraction Process and (II) Storage Time of the Extract on the Hydrolysis of Corn Anylopectin

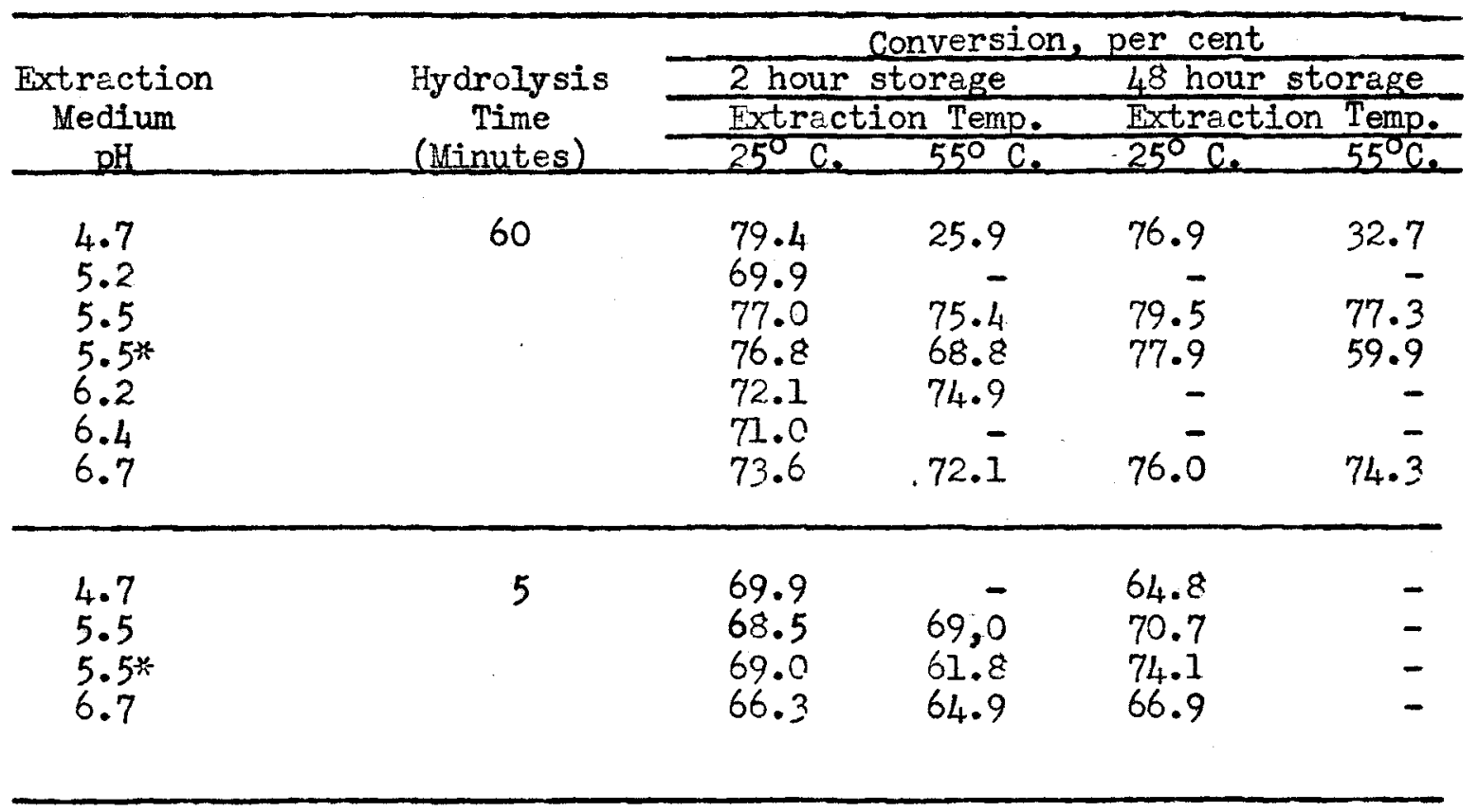

* Unbuffered, control sample 


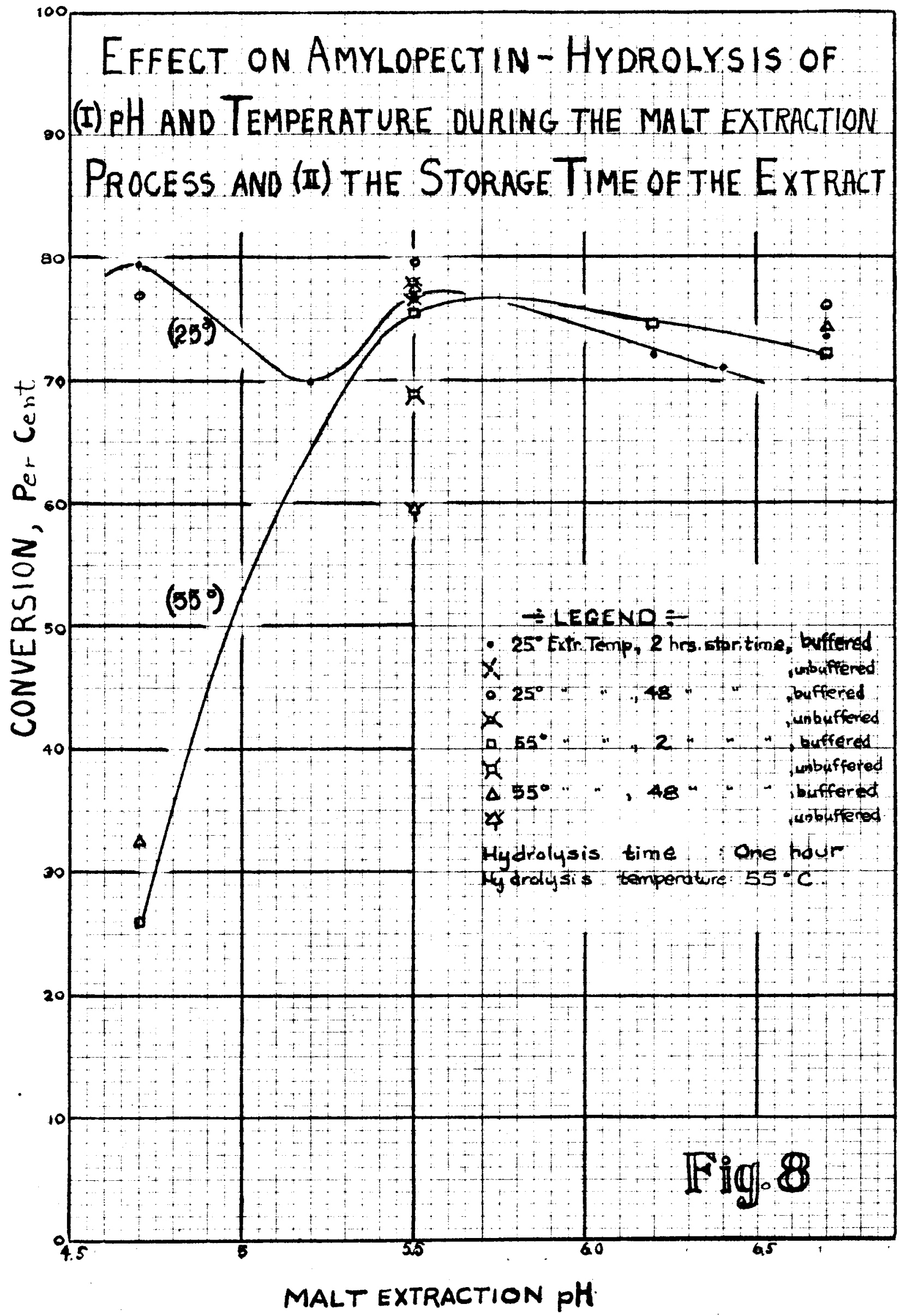


The optimum $\mathrm{pH}$ range of the malt extraction medium occurred apparently between 5.5 and 5.8 for both the $25^{\circ}$ and $55^{\circ}$ C. extraction temperatures. At a low $\mathrm{pH}(4.7)$ there was a great dependence on the extraction temperature; at a low extraction temperature (250 C.), there was good conversion whereas at $55^{\circ} \mathrm{C}$. extraction temperature, the conversion was very low, the rate of decrease from the optimum $\mathrm{pH}$ being rapid as the $\mathrm{pH}$ was lowered.

Whereas the $55^{\circ} \mathrm{C}$. extraction temperature curve showed one optimum range, the $25^{\circ} \mathrm{C}$. curve indicated two optimum ranges, one at the relatively low $\mathrm{pH}$ of approximately 4.7 and the other at pH 5.6 to 5.9. Possibly an optimum for beta-amylase was approached at the Iow $\mathrm{pH}$ and an optimum for alpha-amylase was approached at the higher pH. Apparently the combination of low $\mathrm{pH}$ and high temperature over the 2.5 hour extraction period was very detrimental to the beta-amylase action.

Unbuffered malt, having an initial pH of 5.5, and extracted at $55^{\circ} \mathrm{C}$. , showed lower conversion ability than malt brought to a pH of 5.5 by means of a buffer and extracted at the same temperature; after extraction at room temperature, however, hydrolysis power was much less affected by buffering. Probably this may be explained as a reduction in $\mathrm{pH}$ of an unbuffered malt by heating.

Over the pH range studied, extracts which were stored for 43 hours produced a slightly higher degree of hydrolysis than the unstored extracts. The reason for this is obscure since it is usually 
considered that amylase action decreases on storage. It is possible, however, that some other malt constituent could cause this increased conversion. Apparently the increase in conversion caused by storing malt is not related to $\mathrm{pH}$ or extraction temperature within the range studied in this experiment.

The effect of heat treatment of malt during extraction and the effect of storage time of the treated extract on the power of the extract to hydrolyze com amylopectin are shown in the conversion data presented in Table XII and show graphically in Fig. 9. The malt extracts were prepared as described under "Preparation of Materials Special Malt Fxtract $B^{\prime \prime}$. The quantity of malt used (based on amylopectin) was 65 per cent.

TABLE XII

The Effect of Malt Extraction Treatment and Storage Time of the Futract on the Hydrolysis Power of the Malt Extract

\begin{tabular}{|c|c|c|c|c|c|c|c|c|c|}
\hline \multirow{5}{*}{$\begin{array}{c}\text { Hydrolysis } \\
\text { Time } \\
\text { Period } \\
\text { (Minutes) }\end{array}$} & \multicolumn{9}{|c|}{ Conversion, per cent } \\
\hline & \multicolumn{9}{|c|}{ Malt Extrection Treatment } \\
\hline & \multicolumn{3}{|c|}{$\begin{array}{c}\text { Control - } 2.5 \text { hour } \\
\text { Room Temperature } \\
\text { Extraction }\end{array}$} & \multicolumn{3}{|c|}{$\begin{array}{l}\text { Short Time Heat } \\
\text { Treatment during } \\
\text { Fxtraction }\end{array}$} & \multicolumn{3}{|c|}{$\begin{array}{l}\text { Prolonged Heat } \\
\text { Treatment during } \\
\text { Extraction }\end{array}$} \\
\hline & \multicolumn{9}{|c|}{ Extract Storage Time (Hours) } \\
\hline & 0.5 & -48 & 144 & 0.5 & 48 & 144 & 0.5 & 48 & 144 \\
\hline $\begin{array}{r}1 \\
5 \\
60\end{array}$ & $\begin{array}{l}64.2 \\
67.3 \\
72.4\end{array}$ & $\begin{array}{l}62.5 \\
67.7 \\
77.1\end{array}$ & $\begin{array}{l}41.8 \\
68.9 \\
83.2\end{array}$ & $\begin{array}{l}59.8 \\
66.1 \\
71.5\end{array}$ & $\begin{array}{l}57.0 \\
66.6 \\
80.1\end{array}$ & $\begin{array}{l}53.7 \\
70.1 \\
83.0\end{array}$ & $\begin{array}{l}73.6 \\
75.7 \\
73.6\end{array}$ & $\begin{array}{l}57.0 \\
68.2 \\
78.3\end{array}$ & $\begin{array}{l}63.2 \\
74.3 \\
84.8\end{array}$ \\
\hline
\end{tabular}

a $-15 \mathrm{~min}$. $37^{\circ} \mathrm{C}$, then $15 \mathrm{~min}$. $55^{\circ} \mathrm{C}$. b $-150 \mathrm{~min}$. $355^{\circ} \mathrm{C}$. 


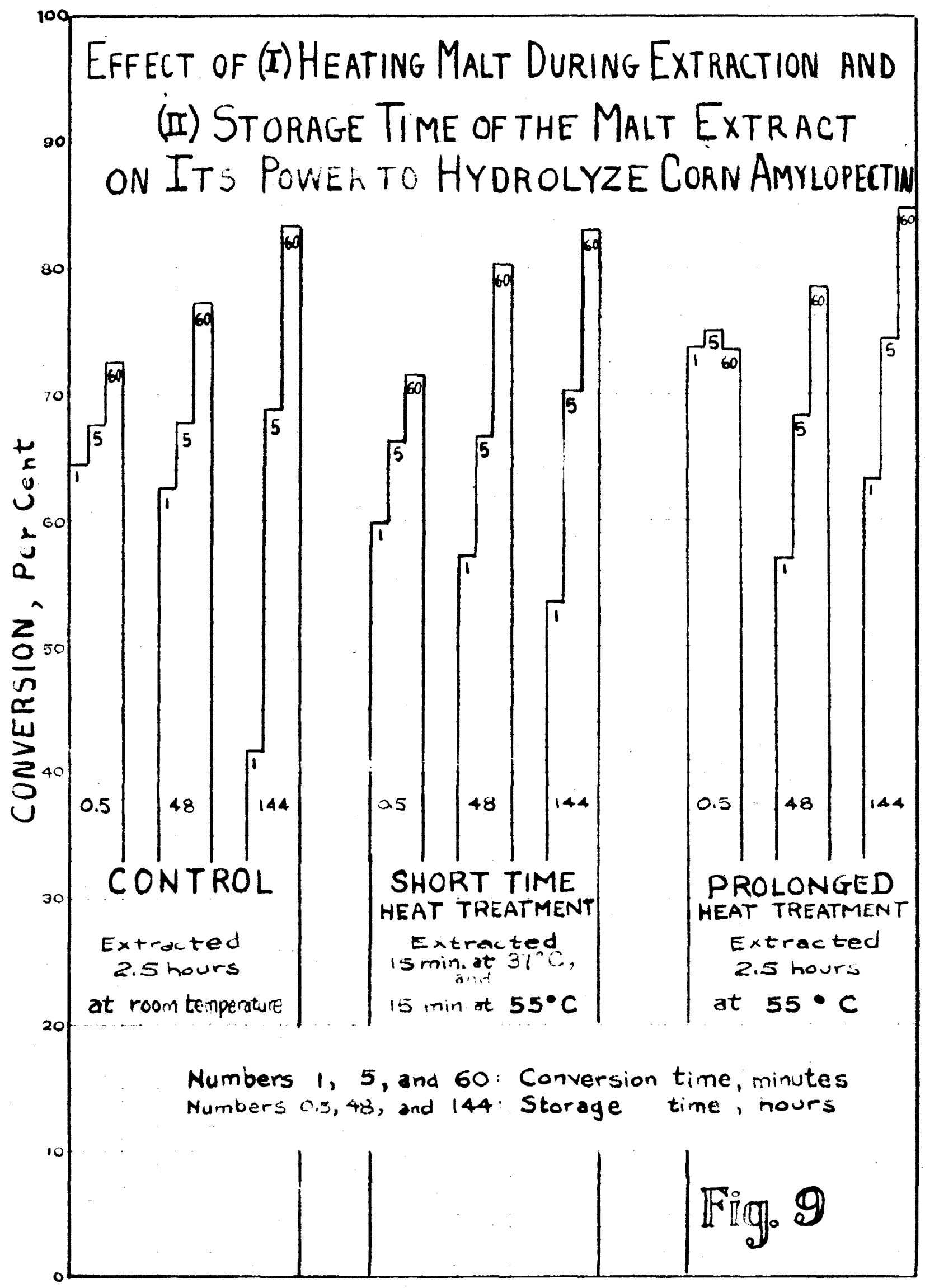


For any particular storage time, previous heat treatment of the malt had little effect on the degree of hydrolysis when the hydrolysis was allowed to proceed for one hour in the presence of an excess of the treated malt. A large excess of malt was used in order to measure the effect of heating on the amylases themselves; if smaller amounts were used, this effect would be masked by the liberation of more free amylase by heating. Using excess malt quantities, small changes in malt quantity have relatively little effect on the degree of hydrolysis.

When the time of hydrolysis was relatively short - one minute or five minutes - the greatest degree of conversion was achieved using malt wich had been extracted 2.5 hours at $55^{\circ} \mathrm{C}$. There was practically no difference between the unheated control and the malt heated for onehalf hour during extraction for the 5 and 60 minute hyrdrolysis periods.

The three malt extracts stored under toluene for 48 and 144 hours apparently had greater conversion ability after storage than when fresh (when a 60 minute conversion time was employed). For the six-day storage period, conversion was increased by approximately 10 per cent. Short storage periods had relatively more effect in increasing hydrolysis ability of the malt extract than longer periods.

If the hydrolysis period was shortened to one minute, the malt extrect samples stored for 48 hours and 144 hours gave a significantly lower degree of hydrolysis than unstored malt. The factor causing increased conversion (as a result of storing the malt extract) appeared to be ineffective under the conditions employed in this experiment, at hydrolysis periods of five minutes or less. 
In general, the results indicated that heat treatment during extraction was ineffective in causing increased degree of hydrolysis when an excess of malt was used; on the other hand, increased storage tine of the extract resulted in a higher degree of hydrolysis provided that the hydrolysis time period was approximately one hour.

To determine the effect of storage of the malt extract on amylopectin hydrolysis at various temperatures and short time hydrolysis, com amylopectin was hydrolyzed using a large excess of the malt extract (102-140 per cent based on amylopectin). Fresh malt extract and 24-hour stored malt extract prepared in the same way as fresh extract were used as the hydrolyzing agents.

The data are summarized in Table XIII and are show graphically in Fig. 10.

TABLE XIII

The Hydrolysis of Com Amylopectin at Various Temperatures by Stored and Fresh Malt Extract

\begin{tabular}{|c|c|c|c|c|c|}
\hline \multirow{2}{*}{$\begin{array}{c}\text { Hydrolysis } \\
\text { Time } \\
\text { (uinutes) }\end{array}$} & \multirow{2}{*}{$\begin{array}{l}\text { Hydrolysis } \\
\text { Temperature } \\
{ }^{\circ} \mathrm{C} .\end{array}$} & \multicolumn{4}{|c|}{ Conversion, per cent } \\
\hline & & Fresh Malt & Extract & $\frac{247 \text { hour }}{\text { Bun I }}$ & $\frac{\text { Stored Extract }}{\text { Run II }}$ \\
\hline 1 & $\begin{array}{l}30 \\
35 \\
40 \\
45 \\
50 \\
61 \\
63 \\
67 \\
70\end{array}$ & $\begin{array}{r}31.4 \\
-\overline{7} \\
44.7 \\
56 . \overline{4} \\
60.8 \\
60.4_{4} \\
56.8 \\
-\end{array}$ & & $\begin{array}{r}54 . \bar{t} \\
64.6 \\
- \\
- \\
- \\
-\end{array}$ & $\begin{array}{r}47.0 \\
59.1 \\
- \\
- \\
- \\
41.0\end{array}$ \\
\hline
\end{tabular}




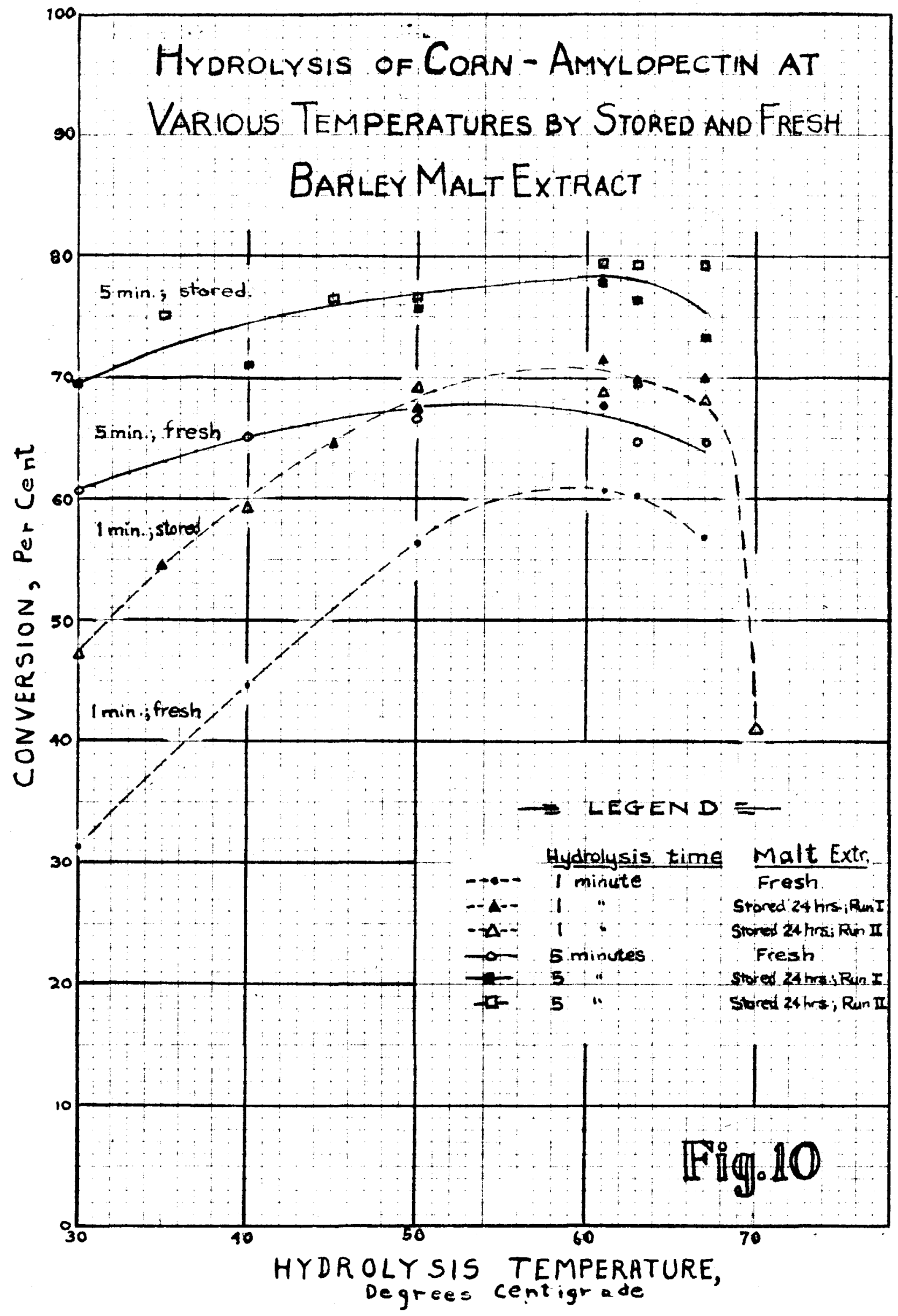


TABLE XIII (Cont'd)

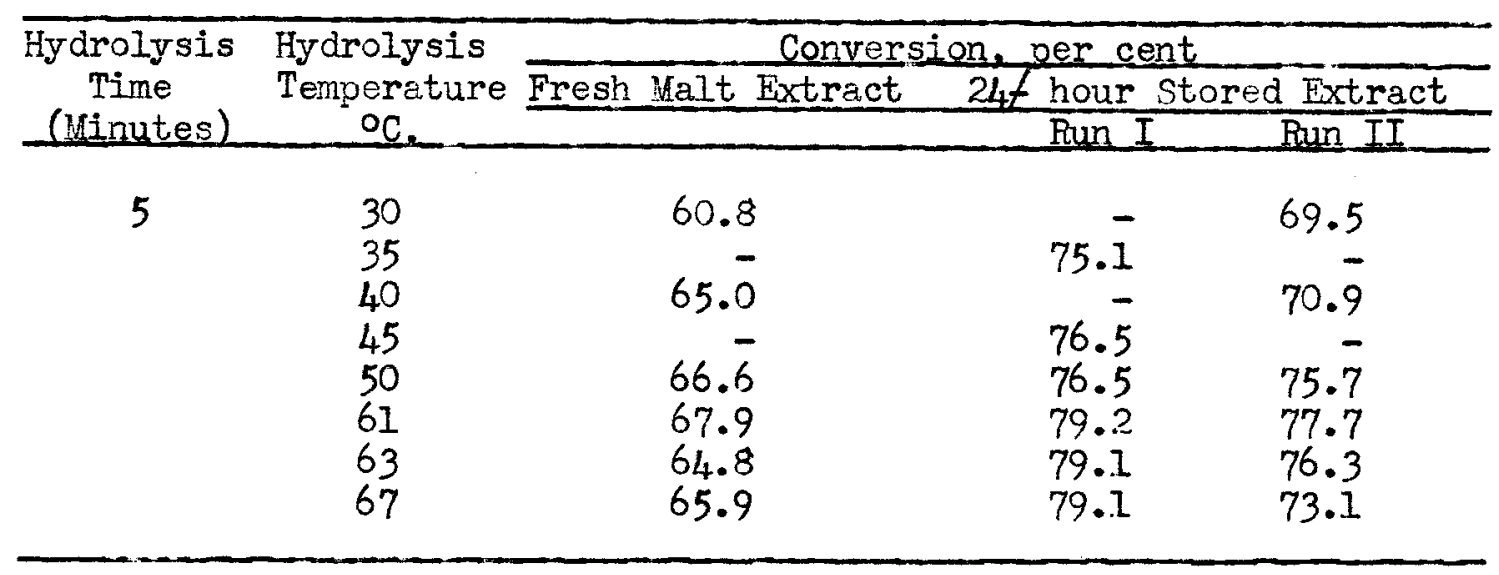

The results indicated that malt extract stored for 24 hours at room temperature effected a greater degree of hydrolysis of com amylopectin than fresh malt extract.

Results of a previous experiment indicated that when a 65 per cent malt quantity (based on amylopectin) was used, an increase in hydrolysis ability of the stored malt extract occurred for a hydrolysis times of one and five minutes (See Fig. 9). On increasing the malt quantity to 138 per cent, a significant increase in hydrolysis occurred for both one and five minute hydrolysis times. This increase was consistent over the entire hydrolysis temperature range studied (30-670 c.). This is further evidence that the factor causing increased hydrolysis as a result of storing malt extract is relatively independent of temperature for the range $30-67^{\circ} \mathrm{C}$.

To identify this factor will require further study. Nothing could be found in the literature to indicate the presence of such a factor in malt or its identity. 
64.

SUMMARY OF RESULTS AND CONCLUSIONS 
Sumary of Results and Conclusions

1. When hydrolyzed by barley malt and then fermented, waxy maize starch (practically pure amylopectin) was converted to a lesser degree and gave lower plant and fermentation efficiencies than corm starch (approximately 79 per cent amylopectin); apparently the amylopectin fraction of starch presents obstacles to conversion to fermentable sugars.

2. Further conversion of both corn starch and waxy maize starch occurred during the fermentation process when malt amylases were present, but there was no further conversion if the amylases were destroyed previous to fermentation.

3. Hydrolysis for different periods of time at $63^{\circ} \mathrm{C}$, , followed by fermentation in the presence of malt arrylases indicated that there was no significant advantage in using a hydrolysis period in excess of 15 minutes; it should also be expected that the shorter time hydrolysis at $63^{\circ} \mathrm{C}$. should leave more amylase a vailable for conversion during fermentation.

4. At $63^{\circ} \mathrm{C}$. hydrolysis temperature, amylose was rapidly and approxi-. mately completely hydroljzed to reducing sugars; amylopectin hydroIysis was 59 , per cent complete at the end of 15 minutes and increased slowly and to only a slight degree with further hydrolysis time.

5. Under various conditions of malt quantity and hydrolysis time, the optimum hydrolysis temperature for corn amylopectin was $52^{\circ}-57^{\circ} \mathrm{C}$. 
(This is a substantially lower temperature than the $63^{\circ} \mathrm{C}$. normally used in distillery practice.) At temperatures above $57^{\circ} \mathrm{C}$, , heat inactivation of the amylases was definitely apparent.

6. The optimum pH range for hydrolysis was apparently 5.5 when the malt quantity was low. However, in the pH range $4.6-6.0$, the effect of change in pH seemed to be relatively slight. (pH level was maintained by buffer substance.)

7. The optimum pH values for extraction of malt amylases at room temperature were apparently 4.7 to 5.5 . At $55^{\circ}$ C. extraction temperature, the optimum was 5.5 ; at lower $\mathrm{pH}$ values, a very detrimental effect on the amylase was noted. At $55^{\circ} \mathrm{C}$. extraction temperature, buffering the extraction medium with phosphate at pH 5,5 prevented loss in amylase activity. With extraction room temperature, the buffer apparently had no effect.

8. When the time of hydrolysis was greater than 10 minutes at $55^{\circ} \mathrm{C}$., the malt quantity required to effect the practical limit of conversion was approximately 11 per cent based on amylopectin. This is less than that normally used (on a starch basis) for grain in distillery practice. Relatively good conversions at low temperatures indicated that possibly even less malt would be effective, since conversion continues during fermentation.

9. Storing the malt extract at room temperature, (between 24 and 144 hours) increased its hydrolysis activity when it was used in relatively 
large amount. Possibly this phenomenon may be attributed to the presence of some specific material which increases in potency or in amount in the malt extract on standing. This increase of activity upon storage seems to be relatively unaffected by changes in temperatures (in the range $30^{\circ}-67^{\circ} \mathrm{C.}$ ) and by changes in $\mathrm{pH}$ (in the range $5.0-6.7$ ). 
68.

REFERENCES 
1. Clark, Mansfield, "The Determination of Hydrogen Ions", p. 214,

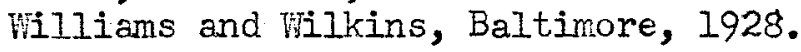

2. Clark, Mansfield, Ibid, p. 200.

3. Freemen, G. G., and Hopkins, R. H., Biochem. J. 30, 446 (1936).

4. Freudenberg, K., and Boppel, H., Ber., 73 B, 609 (1940).

5. Hills, C. H., and Bailey, C. H., Cereal Chem., 15, 351 (1938).

6. Hanes, C. S., Can. J. Research, B 13, 185 (1935).

7. Hanes, C. S., New Phytologist, 36, 101 (1937).

8. Kerr, R. W., "Chemistry and Industry of Starch", p. 162, Academic Press, Inc., New York, 1944.

9. Kerr, R. W., Ibid., p. 297.

10. Kerr, R. W., Ibia., p. 237,

11. Kerr, R. W., "Chemistry and Industry of Starch", p. 24, Academic Press, Inc., New York, 1944.

12. Kneen, Eric, Sandstedt, R. M., and Hollenbeck, C. M., Cereal Chem., 20, 422 (1943).

13. Meyer, K. H., "Advances in Colloid Science", p. 145, Interscience Publishers, New York, 1942.

14. Meyer, K. H., Ibid., p. 173.

15. Meyer, K. H., New Phytologist, 36, 33 (1937).

16. Meyer, K. H., Bernfeld, P., and Press, Helv. Chem. Acta, 23, 845 1940.

17. Meyer, K. H., and Press, J., Ibid, 24, 50 (1941).

18. Meyer, K. H., Wortheim, M., and Bernfeld, P., Helv. Chem. Acta, 23. 864 (1940).

19. Myrback, K., and Ahlborg, K., Biochem. Z. 207, 69 (1940).

20. Ohlsson, Erik, Z. physiol Chem., 189, 17 91930). 
2]. Ohlsson, Erik, Z. . physiol. Chem., 189, 17-63 (1930).

22. Ohlsson, Erik, and Uddenberg, C. F., Z. physiol. Chem., 221, 165-173 (1933).

23. Pacsu, Eugene, and Mullen, James W., Tbid, 63, 1168 (1941).

- 2.4. Pigman, w. W., J. Research Nat'l. Bur. Standards, 33, 115 (1944).

25. Pigman, Vi. W., Jbid, 33, 107 (1944).

26. Pigman, W. W., J. Research Nat11. Bur. Standards, 23, 116 (1944).

27. Rundle, R. E., and Baldwin, R. R., J. Am. Chem., Inc., 65, 554 (1943).

28. Samec, M., and Waldschmidt-Leitz, E., Z. physiol. Chem., 203, 16 (1931).

29. Sandstedt, R. M., Kneen, Eric, and Blish, M. J., Cereal Chem. 16, 712 (1939).

30. Schoch, Thomas John, I. Am. Chem. Soc., 64, 2959 (1942).

31. Schoch, Thomas John, Ibid. 64, 2954 (1942).

32. Schoch, Thomas John, Tbid. 64, 2957-2959 (1942).

33. Schoch, Thomas John, Ibid., 65, 1382 (1943).

34. Sendroy, J., Jr., and Hastings, A. B., J. Biol. Chem., I, 783 (1927).

35. Stamberg, O. F., and Bailey, C. H.: Cereal Chem. 16. 330-335 (1939).

36. Stark, W. H., Adams, S. I., Scalf, R. F., and Kolachov, Paul, Ind. Eng. Chem., Anal. Ed., 15, 443-4,46 (1943).

37. Stark, W. H., Adams, S. I., Scalf, R. E., and Kolachov, Paul, Ibid.: 15, 444 (1943).

38. Stenstam, T. B., and Ohlsson, Erik, Z. chysiol. Chem., 226, 265-271 (1934).

39. Stiles, H. R., Peterson, W. H. and Fred, E. B., J. Bact., 12, $428-435(1926)$.

40. Wagner, Bernhard, MWagner's Tabellen zum Eintauchref raktometer, Neudruck der Tabellen fur Aethyl-alkohol", published by the author, Sondershausen (1932). 